\title{
Espaço, paisagem e população: dinâmicas espaciais e movimentos da população na leitura das vilas do ouro em Minas Gerais ao começo do século XIX ${ }^{1}$
}

Alexandre Mendes Cunha Cedeplar/UFMG

\section{RESUMO}

O objetivo principal deste artigo é interpretar as transformações no espaço urbano das vilas do ouro mineiras na passagem do século XVIII para o XIX, pensando particularmente as transformações na paisagem e na demografia, de forma articulada à dinâmica econômica da capitania. Destacam-se dois núcleos — Vila Rica (Ouro Preto) e São João del Rey - , mas transcendendo a análise para o conjuntos dos câmbios entre o urbano e o rural em Minas Gerais no período. Três são os principais grupos de fontes utilizados: relatos de viajantes, iconografia, e listagens ou mapas populacionais. Palavras-chave: Minas Gerais; Paisagem; Urbano-rural.
ABSTRACT

This paper intends to contribute to the interpretation of the changes in the urban space of the gold mining villages in Minas Gerais at the end of $18^{\text {th }}$ century and the beginning of $19^{\text {th }}$. It focuses particularly the transformations concerning landscapes, demography changes, and economic dynamics of the region. Two cities focused: Vila Rica (Ouro Preto) and São João del Rey, but the analysis tries to understand the exchanges between urban and rural spaces in Minas Gerais as a whole. The research is based especially on reports of foreign travelers, iconography, and demographic lists or maps.

Keywords: Minas Gerais; Landscape; Urban-rural changes.

A virada do século XVIII para o XIX na capitania de Minas Gerais é responsável por dar visualidade a transformações substantivas na dinâmica econômica. Por um lado isso remonta processos que já tinham curso desde os primeiros anos da formação do território, mas incisivamente é essa conjuntura de fim de século que coloca em evidência transformações internas e externas que bem qualificam esse tempo como um ponto de inflexão na história de Minas. $\mathrm{O}$ arrefecimento final da economia do ouro e a partir de 1808 a ruptura do arranjo 
de forças que marcava o sistema colonial são as notas principais de um contexto que fazia mais explícita uma ordem econômica em que cada vez mais pesaria, no arranjo da economia mineira, o mercado interno e o comércio de gêneros de subsistência com a praça do Rio de Janeiro, residindo aí o espaço ampliado de um processo de expansão das áreas de produção agropecuária nas Minas.

Este painel um tanto esquemático de transformações incisivamente amplas e avessas a datações por demais precisas serve para aludir a um problema que só mais recentemente, com o levantamento extensivo de bases de dados populacionais para o começo do século XIX, tem sido possível contemplar, ainda que de forma um tanto indireta. Trata-se de buscar entender os ritmos de ocupação do território mineiro no começo do século XIX, e nisso os fluxos de migração entre os espaços urbanos e rurais e entre regiões distintas do território. Deslocamentos que se insinuam já no final do século XVIII entre a região originalmente identificada como as 'Minas Gerais' e o eixo sul do território, ou região 'Campos Sul', como se nomeou em recente exercício de regionalização para o século XVIII (Mapa 1$).{ }^{2} \mathrm{O}$ debate sobre essas questões, todavia, ainda é bastante acanhado na historiografia, sendo particularmente o tema da ruralização mineira no começo do século XIX um tema controverso. O presente ar-

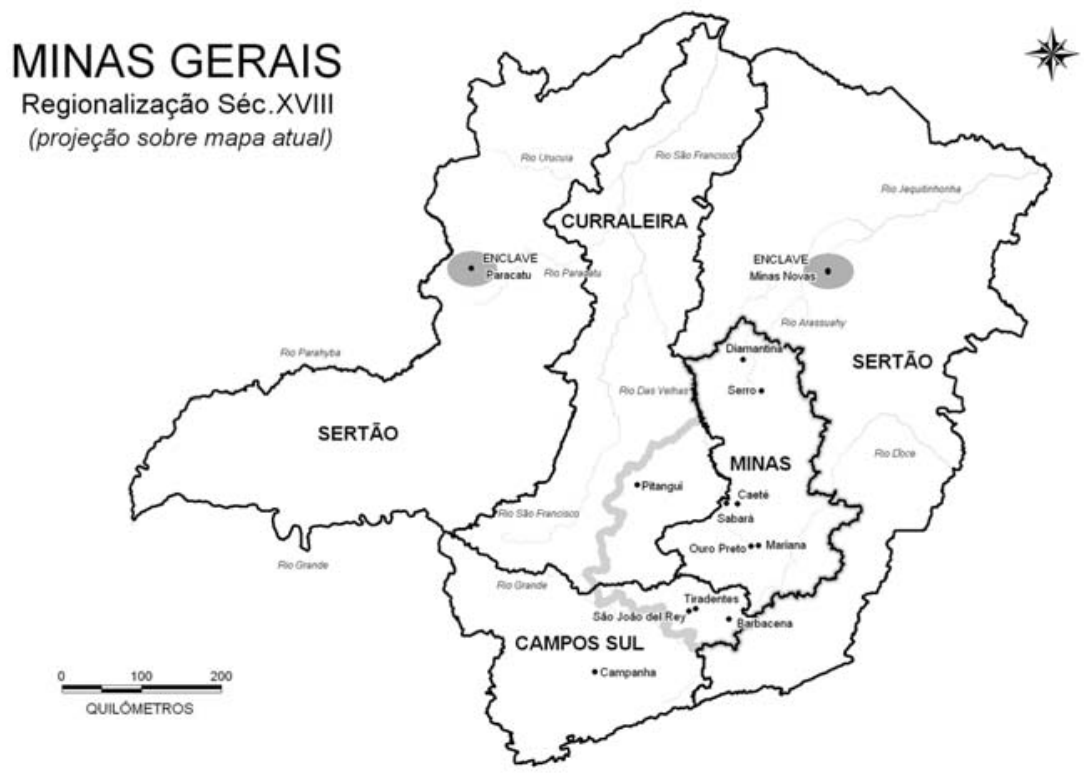

Mapa 1: Regionalização para o século XVIII 
tigo pretende contribuir, portanto, na definição de certo horizonte de perspectivas em que se reforça o argumento das transferências populacionais dos espaços citadinos do antigo núcleo minerador para as áreas de expansão agrícola desde o último quartel do século XVIII, buscando destacar o essencial desse processo a partir do cruzamento de fontes de natureza diversa. São utilizados, assim, dados sobre as paisagens urbanas extraídos dos relatos de viajantes estrangeiros que estiveram em Minas no começo do século XIX e de iconografia do período, bem como pirâmides de distribuição etária para núcleos selecionados, construídas basicamente a partir das listas nominativas dos anos de 18311832. A análise restringe-se ao antigo núcleo minerador central e às áreas de expansão do eixo sul do território mineiro, sendo focados especialmente os núcleos de Vila Rica (Ouro Preto) e São João del Rey, e suas áreas de influência.

\section{A PAISAGEM URBANA DAS VILAS DO OURO: APROXIMAÇÕES}

A visão das Minas ao começo do século XIX oferece, no que diz respeito à materialidade da paisagem natural, o resultado de um século de mineração em encostas escavadas ou nos leitos de rios revolvidos. A visão das cidades, por sua vez, surpreende um conjunto de tempos distintos somados no espaço. Ritmos do desenvolvimento citadino a partir de todo o resultado construtivo do século XVIII em casas, igrejas, edifícios públicos, e particularmente nas obras que à virada do século esperavam conclusão. Desse panorama das cidades marcavam-se fortemente as impressões de cenários urbanos florescentes, por um lado, ou dos que iam na sorte do abandono, por outro. Esses retratos vivos do tempo tiveram aos olhos e ouvidos os viajantes estrangeiros que chegaram ao território mineiro na primeira metade do século XIX, testemunhas de primeira hora, exatamente naquele momento particular ao qual ainda chegava quase incólume o peso do século XVIII, muito embora já dentro de tudo que mudava e precipitava no Brasil do novo século.

Os relatos desses viajantes compõem assim um precioso conjunto documental para a análise desse tempo se tomados no conjunto das impressões sobre as paisagens naturais e humanas. A dificuldade de se trabalhar com o universo de observações subjetivas, um dos principais óbices, equilibra-se entretanto com a crítica atenta, o uso extensivo de vários dos relatos e o concurso de outras fontes em paralelo, como por exemplo as fontes iconográficas ou os dados populacionais. Mais acertado também é o trabalho com essas fontes quando, como aqui, o objetivo é a comparação de áreas distintas entre 
as percorridas pelos mesmos viajantes, uma vez que vão assim unificadas as observações no mesmo quadro de relações subjetivas.

De forma geral, os relatos, em suas descrições concernentes às paisagens de Vila Rica (hoje Ouro Preto) e São João del Rey, as duas dessas vilas do ouro que serão aqui trabalhadas, fazem apresentar, por um lado, certa feição decadente para a primeira ao começo do século XIX, mesmo entre as narrativas que ressaltam a posição de destaque dessa cidade no comércio, e por outro, o viço e a vitalidade da segunda pela mesma época. Essa impressão perpassa várias das obras, e a formação de um elenco de posicionamentos coincidentes nos relatos ajuda a corroborar, mas também problematizar as considerações gerais. $\mathrm{O}$ cuidado com os significados próprios dos termos usados pelos viajantes para suas descrições, deve ser também tema de interesse. A idéia de pitoresco, e a simpatia com a visão geral de uma cidade, por exemplo, muitas das vezes relacionavam-se mais diretamente ao sítio em que ela estava fincada, ou seja, o relevo, a vegetação ou mesmo as condições climáticas do lugar, do que com qualquer atributo da paisagem urbana propriamente dita. As repetidas leituras da fisionomia 'triste' de Vila Rica são, neste sentido, muito mais relacionadas ao escarpado do relevo, à névoa úmida e às chuvas comuns à cidade, do que propriamente à decadência da vitalidade urbana. Não obstante, observações sobre 'casas abandonadas,' 'casas caindo', 'obras interrompidas', contrapondo-se a 'casas muito brancas, recém caiadas', 'telhados vermelhos, ainda não enegrecidos', entre outras tantas observações, são índices mais objetivos, de realidades em que o espaço da cidade era alvo de maior ou menor desenvolvimento no momento em que por elas passaram esses visitantes estrangeiros.

São João del Rey tem sua ocupação inicial marcada por uma sobreposição das lavras com os espaços da vida cotidiana. A despeito de tentativas das autoridades de transferir o núcleo para lugar mais aplainado, a cidade se adensa mesmo à encosta da Serra do Lenheiro, à margem esquerda do córrego Tejuco. ${ }^{3}$

A ocupação da margem direita se deu em ritmo bem mais lento, acelerando muito o seu crescimento, entretanto, a partir da virada do século. A centralidade urbana que a cidade sustentaria ainda por alguns anos no começo do século XIX é filha direta de sua importância como entreposto comercial, o que por sua vez alimenta toda uma estrutura de serviços urbanos na qual se destacam artífices dos mais variados ofícios. A posição de sede da comarca do Rio das Mortes demarca também o espaço de variadas posições burocráticas e militares e de espaços de manutenção da vida cotidiana que vão além da típica ocupação aos domingos e dias festivos, que caracterizaria a maior parte dos núcleos menores que foram se formando, mormente na região sul do território.

Auguste de Saint-Hilaire, com a autoridade de quem percorreu quase to- 
das as regiões das Minas, em pontos diversos de seus relatos tece observações acerca do reduzido número de pessoas que residiam nas localidades de menor porte durante a semana, o que constitui um claro indício da força do processo de ruralização que marca o território na primeira metade do século XIX. Passando pelo julgado de Araxá em 1819, Saint-Hilaire comenta:

Durante a semana a maioria das casas de Araxá fica fechada. Seus donos só ali aparecem aos domingos, para assistirem à missa, passando o resto do tempo em suas fazendas. Só permanecem nas cidades, nos dias de semana, os artesãos — alguns dos quais bastante habilidosos — as pessoas sem profissão, alguns comerciantes e as prostitutas. O que acabo de dizer aqui pode ser aplicado praticamente a todos os arraiais da Província de Minas. ${ }^{4}$

Faz-se importante aqui uma breve digressão no sentido de qualificar que a própria forma da complexificação da economia mineira coloca fundamentalmente em questão as transformações processadas entre o urbano e o rural. O urbano seria assim responsável, a partir das centralidades criadas no século XVIII, por deflagrar ou no mínimo acentuar a especialização das atividades econômicas, e nisso a diferenciação espacial. A ruralização, por sua vez, não seria resultado somente do desenvolvimento do campo com relativa autonomização de circuitos de realização econômica, mas também, de uma relação nova e específica com os espaços citadinos intermediários que ao começo do século XIX expandem seu número nas áreas mais dinâmicas da economia de base agropecuária, cumprindo funções de entrepostos e centro de serviços e articulando a teia econômica. Núcleos citadinos em expansão, rede de cidades adensando-se, mas, no entanto, sem representar um reforço de um processo urbano de produção coletiva e social do espaço, bem como sem reforçar a própria vida urbana nesses núcleos. Ou seja, o tema da ruralização na virada para o século XIX não pode ser entendido nem como uma continuação do desenvolvimento do campo por conta da agricultura e pecuária, já em evidência na primeira metade do século XVIII, tampouco como algo apartado da urbanização. Trata-se, sim, de um processo espacial complexo, fruto da própria complexificação da base econômica, produzindo novas relações de centralidade, e nisto bases para novo desenho regional, e de forma mais ampla, neste imbricamento de urbano com o rural, possibilitando interpretações novas e com outros pressupostos para certos processos sociais e políticos em curso nas Minas desse tempo.

São João del Rey, retomando o curso da análise, colecionaria por sua vez descrições muito próximas de todos os viajantes estrangeiros que por lá pas- 
saram nas primeiras décadas do século XIX, atestando um quadro distinto desses arraiais habitados somente ao final da semana. Johann Emanuel Pohl, por exemplo, diria de sua visita em 1818 que "esta cidade figura entre as mais limpas e alegres que já encontrei no Brasil", sendo agradável e "risonha" a vista proporcionada por suas casas "limpamente caiadas e com pomares verdes, exuberantes, em que se erguem belas bananeiras”. ${ }^{5}$ No mesmo ano lá estiveram Johann Baptist von Spix e Carl Friedrich Philipp von Martius — que diriam de como suas "numerosas casas de um branco deslumbrante" ajudam a compor o "aspecto de beleza romântica" da paisagem - ${ }^{6}$ e o negociante inglês John Luccock, que somaria outros tantos detalhes às descrições, dizendo que

a mistura de numerosas igrejas com as casas, de telhas vermelhas e ainda não enegrecidas pelo fumo, de telhados não deformados pela intromissão de chaminés, de paredes feitas limpas e alvas pela aplicação de argamassa e caiação, de calçamento cor-de-cinza das ruas, das areias amarelentas do rio e do verde dos jardins, formava um quadro pitoresco e interessante. ${ }^{7}$

Em 1824 chega à cidade na comitiva liderada pelo barão Georg Heinrich von Langsdorff o pintor e desenhista Johann Moritz Rugendas, que em suas notas de viagem reforça as cores principais desses outros relatos ao dizer da "brancura" e "limpeza" das casas da cidade, e da "rica vegetação que cerca as residências dispersas pela encosta das montanhas e pelos vales vizinhos". Charles Fox Bunbury, alguns anos mais tarde, em 1835, vai pelo mesmo caminho, argumentando tratar-se de "uma cidade menor que Ouro Preto, porém mais limpa e mais bem construída, as ruas mais largas, mais regulares e mais bem calçadas e as casas com um aspecto bem mais moderno". ${ }^{9}$ Rugendas é também o responsável por um registro pictórico da cidade naquele momento das primeiras décadas do século XIX, que mesmo não permitindo ver com maior proximidade as tramas das construções, oferece grande interesse por conta da quase ausência de fontes iconográficas para a cidade no período. (Figura 1) Trata-se de uma aquarela tomada à margem direita do córrego Tejuco, que corta a cidade ao meio e que à época tinha seu leito bastante largo. Vê-se o maciço principal da serra do Lenheiro, e o conjunto natural encontra-se representado com bastante acuidade no que diz respeito ao relevo ou ao curso do rio, mas não se pode dizer o mesmo do casario e das demais obras, ou mesmo da vegetação. A representação é contudo de traços leves e esquemáticos, sendo até mesmo os elementos do primeiro plano apenas esboçados, assim como certos conjuntos construtivos são resumidos a alguns poucos elementos, e áreas de vegetação a certas manchas de cores. Se tomado 


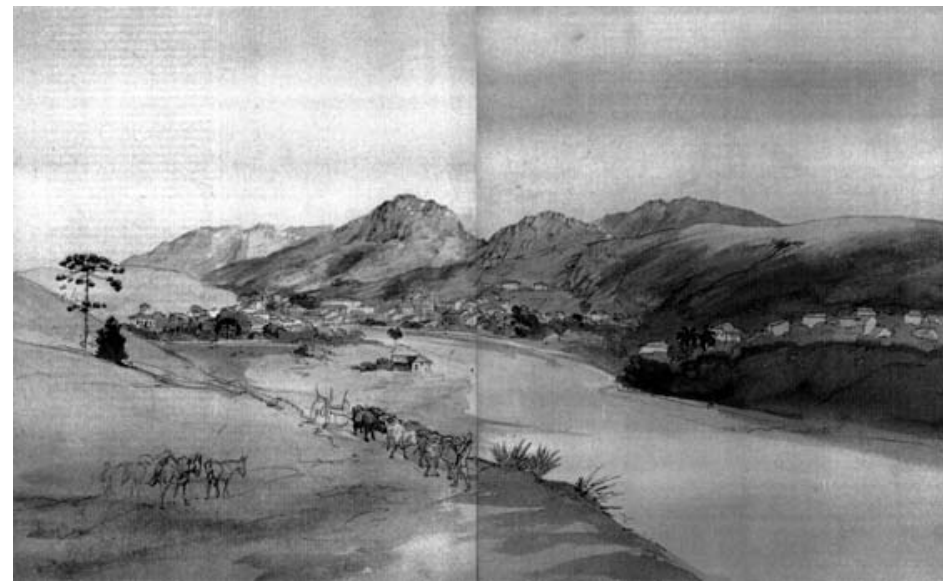

Figura 1: Vista de São João del Rey, 1824 - Johann Moritz Rugendas.

Fonte: Revista Oceanos, Lisboa, Comissão Nacional para as Comemorações dos Descobrimentos Portugueses, n.41 (“A Construção do Brasil Urbano”), jan.-mar., 2000.

em comparação com uma litogravura que aparece publicada na obra de Robert Walsh (Figura 2), que esteve na cidade poucos anos depois de Rugendas, em 1828, as diferenças são flagrantes. Ainda que um tanto imperfeito no que diz respeito à proporcionalidade do conjunto, e com alguns problemas na representação de algumas construções - como na igreja do Carmo, pesada e

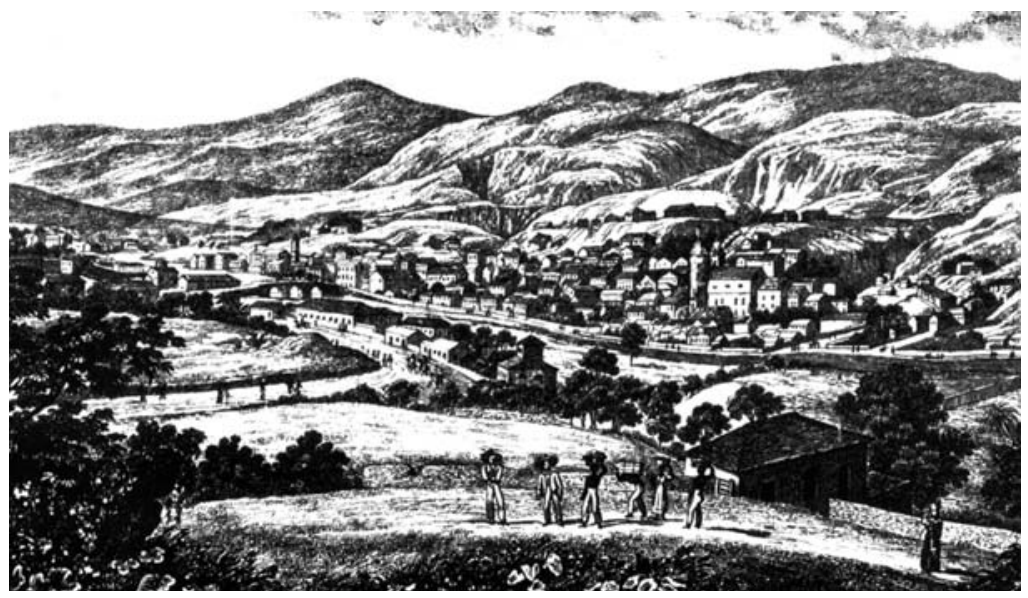

Figura 2: Vista de São João del Rey, 1828 - Robert Walsh.

Fonte: Robert Walsh. Notícias do Brasil. Belo Horizonte: Itatiaia; São Paulo: Edusp, 1985. v.2. 
com disposição truncada de seus volumes - , o desenho de Walsh revela com muito mais precisão a área construída na margem esquerda do rio, onde a cidade se originou. Percebe-se então uma área substantivamente maior que a esboçada por Rugendas. Vê-se também na gravura de Walsh uma das duas pontes de pedra que ligam os dois bairros e, um tanto escondida, a matriz do Pilar, que também se divisa na paisagem de Rugendas, e que ainda nesse momento ostentava sua fachada antiga, com uma só torre, exatamente na forma como a descreveu Luccock em seu relato. ${ }^{10}$ Uma parte considerável da cidade, tanto à margem esquerda, no espaço que vai da primeira até a segunda ponte de pedra e que delimita faixa amplamente povoada de São João, quanto à direita, que responde pelas terras mais densamente ocupadas a partir do final do século XVIII, não se avista nas gravuras. Os dois bairros, entretanto, segundo informa Raimundo de Cunha Matos, pela década de 1830 seriam quase equivalentes em tamanho, estando nessas vistas imperceptíveis por conta das sombras do relevo. ${ }^{11}$

Novamente em relação ao casario, se tomadas as cores da aquarela de Rugendas em paralelo à sua descrição literal da brancura das construções recentemente caiadas, tem-se um bom indício para animar o quadro estático como um cenário 'florescente'.

Não obstante a paisagem natural e urbana ser considerada com atenção pelos viajantes, são mesmo as descrições do comércio na cidade os elementos centrais para a composição de uma imagem da vitalidade de São João naquele tempo. Do plano geral das vistas pode-se alternar assim para algumas observações de detalhe nas descrições. Walsh afirma que "a maioria das casas se compõe de lojas de aparência bem cuidada e cheias de mercadorias de várias procedências", frisando como o comércio de gêneros locais e importados dava "a impressão de ser ali uma próspera e florescente cidade". ${ }^{12}$ Pohl seria ainda mais enfático ao dizer que "quase cada casa, aqui, tem um armazém, ou uma venda”. ${ }^{13}$ Spix e Martius dão também sua impressão, ressaltando que:

ruas calçadas, belas igrejas guarnecidas com pinturas de artistas nacionais, lojas fornecidas de todos os artigos de luxo e do comércio europeu, muitas oficinas etc., indicam a riqueza do lugar que, por suas transações com o sertão, é considerado entre os mais animados do Brasil. ${ }^{14}$

Essas imagens de São João del Rey no começo do século XIX podem ser colocadas em interessante contraste com as visões de Vila Rica no período. Estritamente no que diz respeito à paisagem urbana, os viajantes que estiveram na cidade não deixaram de reconhecer o número e a qualidade de suas 
principais construções, em claro destaque dentro do panorama citadino das Minas. As expectativas de uma cidade de fausto, construída com os rendimentos do ouro, todavia, teimaram em trair alguns visitantes mais desavisados, acabando por reproduzir leituras por demais depreciativas, pouco condizentes com a real condição da cidade. O ponto é que com o começo do século XIX torna-se patente em Vila Rica uma forte retração populacional, o que tem como claro reflexo o abandono de muitas das casas da cidade, e de forma um pouco mais ampla, o arrefecimento das obras públicas, ficando incompletos, anos a fio, inúmeros edifícios. Não obstante, agravaria essa impressão a soma da violenta destruição da paisagem natural por conta das atividades minerais e a própria situação topográfica, pouco favorável à construção de uma cidade. Mawe revela-se admirado com a pobreza relativa da cidade, dizendo que "das duas mil casas, um número considerável não estava alugado, e o aluguel das outras baixava cada vez mais". ${ }^{15}$ Auguste de SaintHilaire, em 1816, argumenta também sobre o abandono de muitas casas, expondo alguns dados gerais que são relativamente bem aceitos pela historiografia como aproximações demográficas confiáveis:

Contam-se em Vila Rica cerca de duas mil casas. Essa vila floresceu enquanto os terrenos que a rodeiam forneciam ouro em abundância; à medida, porém, que o metal foi se tornando raro ou de extração mais difícil, os habitantes foram pouco a pouco tentar fortuna em outros lugares, e, em algumas ruas, as casas estão quase abandonadas. A população, que chegou a ser de 20 mil almas, está atualmente reduzida a 8 mil, e esta vila estaria mais deserta ainda se não fosse a capital da província, a sede da administração e a residência de um regimento. ${ }^{16}$

Saint-Hilaire também oferece descrições mais precisas dessas casas, dizendo que eram, na maioria, construídas de barro e muito mal conservadas, atestando "os parcos recursos dos habitantes". Os telhados e as paredes eram esmaecidos ou pardos, e algumas poucas construções caiadas a fresco, no meio da paisagem, faziam "ressaltar mais ainda as cores sombrias das casas próximas". ${ }^{17}$

A situação dos caminhos de entrada na cidade revelava, por vezes, os mais evidentes sinais do arrefecimento da economia de base urbana. Pohl daria descrições interessantes desses caminhos, particularmente dos acessos a quem vem desde Mariana, dizendo que "particularmente ruins são as casas onde começa a cidade", em geral, "choças baixas, não caiadas, muitas já em escombros", que "concorrem não pouco para tornar negativa a primeira impressão que se tem de Vila Rica”. ${ }^{18}$ A partir de sua minuciosa descrição, é possível identificar com propriedade as continuidades da teia urbana do núcleo de Vila Ri- 
ca, sendo efetivamente a faixa que liga as igrejas matrizes de Antônio Dias à do Pilar a única parte da cidade que apresentava maior adensamento e seqüência menos interrompida nas construções, estando as áreas menos centrais cobertas somente por casas bem espaçadas. A visão da praça central da cidade e do conjunto urbano dessa faixa mais adensada de Antônio Dias pode ser recuperada nas paisagens pintadas por Arnaud Julien Pallière muito provavelmente entre 1820 e 1822 (Figuras 3 e 4). ${ }^{19} \mathrm{~A}$ iconografia referente a Vila Rica no período está muito longe de ser ampla, especialmente em com-

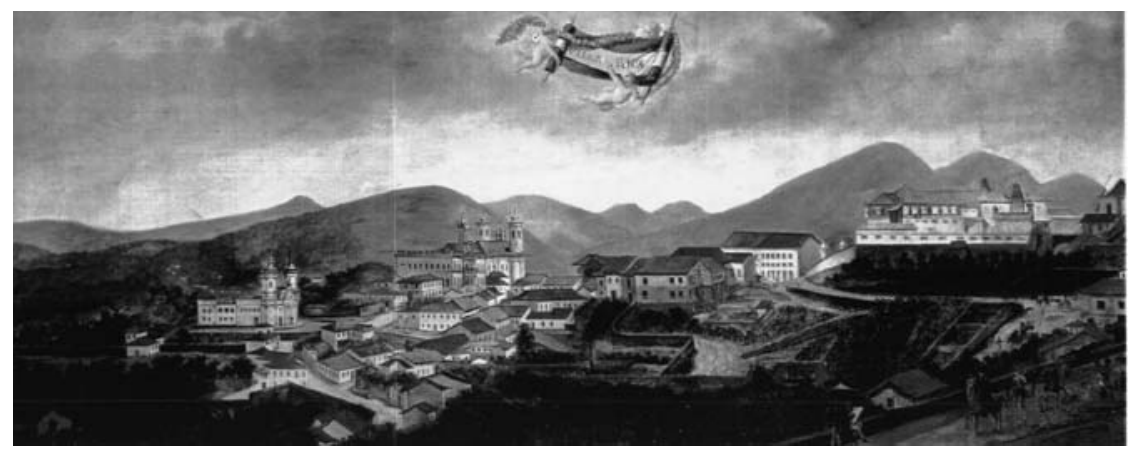

Figura 3: Vista de Vila Rica (Antônio Dias), c.1820 - Arnaud Pallière (Museu da Inconfidência, Ouro Preto). Fonte: Nelson Aguilar (curador geral). O olhar distante / The distant view. Catálogo da Mostra do Redescobrimento - 2000 (Parque Ibirapuera, SP). São Paulo: Associação Brasil 500 Anos/Artes Visuais, 2000.

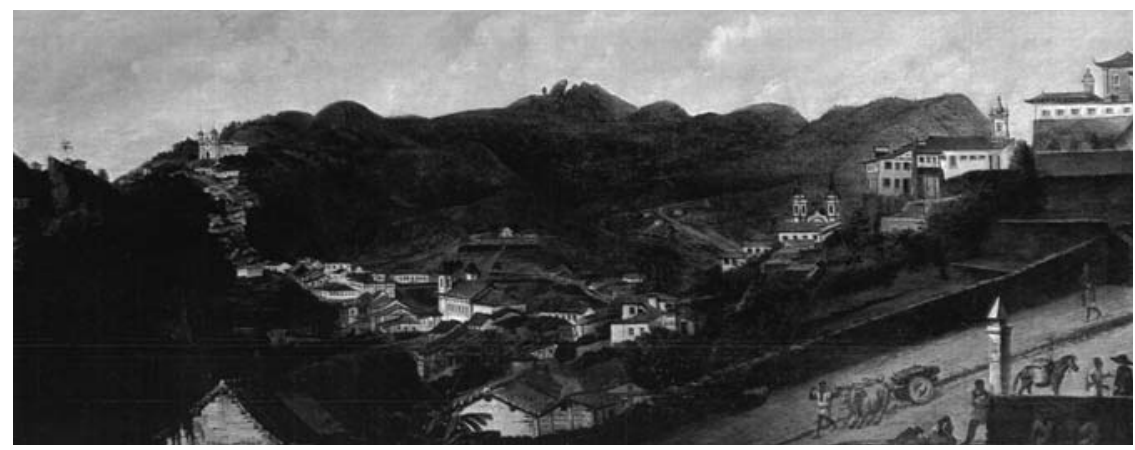

Figura 4: Vista de Vila Rica (Antônio Dias), c.1820 - Arnaud Pallière

(Col. Particular, Rio de Janeiro). Fonte: Nelson Aguilar (curador geral). O olhar distante / The distant view. Catálogo da Mostra do Redescobrimento - 2000 (Parque Ibirapuera, SP). São Paulo: Associação Brasil 500 Anos/Artes Visuais, 2000. 
paração com as vistas produzidas para o Rio de Janeiro por todo o século XIX; não obstante, dentro do contexto das Minas, é sem dúvida a paragem que mereceu mais representações, algumas delas dispersas em arquivos particulares e que só mais recentemente puderam chegar aos olhos de público mais amplo. Outro ponto problemático é que se o alvo são as inferências sobre a paisagem urbana e os exemplos arquitetônicos, só perifericamente pode-se achar subsídio, uma vez que a maioria das vistas de Minas no período foram executadas por viajantes, que no mais das vezes iam mais interessados em paisagens naturais e no elemento humano e animal do que nas construções urbanas. Essas vistas pintadas por Pallière - uma delas a conhecida tela pertencente ao acervo do Museu da Inconfidência e a outra um exemplar bem menos visto, pertencente a um colecionador privado no Rio de Janeiro - constituem os mais importantes registros pictóricos da cidade para o período. As imagens dão conta exclusivamente do bairro de Antônio Dias, podendo-se ver na mais conhecida todo o conjunto que se descortina desde um ponto acima do caminho das Lajes tendo a praça ao centro (Figura 3), e na outra o interior do bairro, tomado da entrada da rua dos paulistas, colocando em perspectiva a matriz e subindo a ladeira a Santa Efigênia do Alto da Cruz, estando ao fundo, no centro exato da tela o pico do Itacolomi (Figura 4). Um dos pontos interessantes dessa última paisagem é exatamente o tema da dispersão das áreas construídas. Pode-se ver com clareza que as casas se enfileiravam em uma linha contínua entre Santa Efigênia e a matriz de Nossa Senhora da Conceição, para dali se adensaram na área mais próxima à praça central. Para além disso, não obstante, o que se vê são só construções esparsas. Na tela do Museu da Inconfidência também são bem presentes esses espaços vazios de construções, inclusive na entrada do caminho das Lajes, aberto em 1782 por D. Rodrigo de Menezes, e que em outro interessante desenho, atribuído a Martius, aparece completamente despovoado. É importante destacar, a despeito de certos detalhes truncados e da ausência de alguns elementos da paisagem construída, a acuidade e precisão dessas vistas na representação do cenário urbano de Vila Rica. Outra representação bastante conhecida de Vila Rica no começo do século XIX é a gravura que aparece na edição original do relato de viagem de Pohl, mas que apresenta, ao contrário da tela de Pallière, imperfeições na posição relativa das construções e nas proporções da paisagem, que decorrem do fato de Pohl só ter realizado um esboçßo da gravura em sua viagem, sendo este depois trabalhado para a edição da obra na Europa, por Thomas Ender, que por sua vez nunca estivera na cidade (Figura 5). ${ }^{20}$

A despeito dessas imperfeições na proporção do desenho, caracterizada 


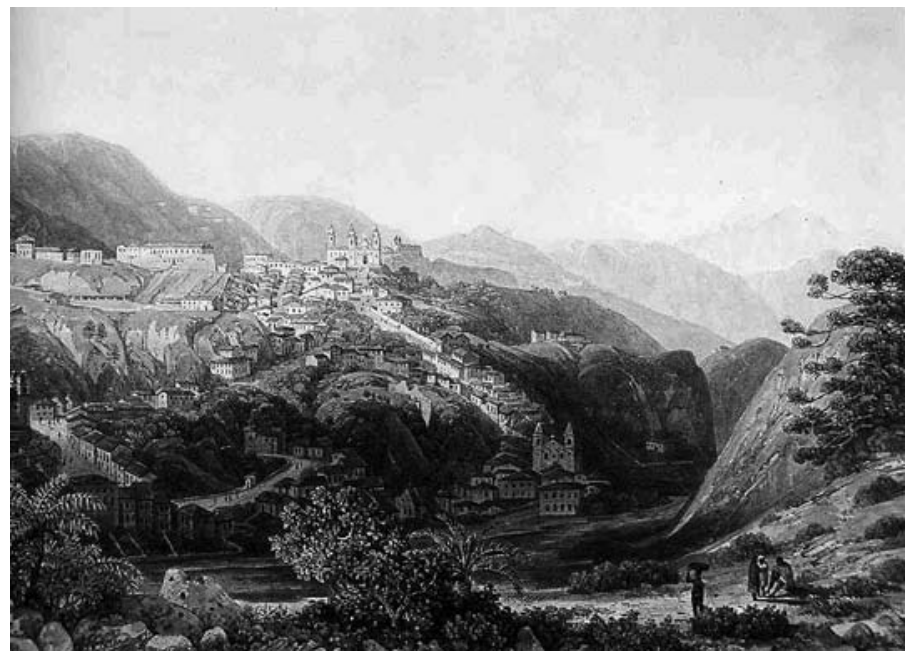

Figura 5 - Vista de Vila Rica (Ouro Preto), 1820 - Johann Emanuel Pohl e Thomas Ender. Fonte: Robert Wagner; Júlio Bandeira. Viagem ao Brasil nas aquarelas de Thomas Ender, 1817-1818. Petrópolis: Kapa, 2000. Tomo 3.

por uma redução na largura original da vista, implicando uma conformação muito mais abrupta do relevo do que efetivamente se verifica, vários pontos de interesse podem ser desdobrados do desenho, especialmente por se tratar de uma vista do bairro de Ouro Preto, que completa assim, de alguma forma, as vistas de Pallière para Antônio Dias. Vê-se também na gravura de Pohl que os espaços de maior densidade de construções estão mesmo circunscritos às principais vias. Também é muito interessante notar que àquela altura, 1820, as obras de várias das igrejas de Vila Rica encontravam-se ainda inconclusas. Apresentam-se assim com partes faltando os templos de Nossa Senhora das Mercês e da Misericórdia, de São José e de São Francisco de Paula. ${ }^{21}$

Um tema bastante difícil de ser rastreado a partir dessas gravuras, mas de grande importância para a reflexão aqui proposta, é o do precário estado de conservação do casario naquele começo do século XIX. Na maior parte das telas a grande distância em que são tomados os objetos e o próprio foco das atenções tendem a tornar difusas algumas características da paisagem construída. Mesmo padecendo desses problemas, essa pouco conhecida tela de Pallière que se ocupa da paisagem até a igreja de Santa Efigênia do Alto da Cruz é uma exceção importante. Nela é possível ver, mesmo a distância, a precariedade do casario, espacialmente atentando-se para as partes próximas à ladeira de Santa Efigênia e para além das áreas mais valorizadas circunscritas 
ao adro e vizinhanças da matriz. É possível ver algumas paredes rachadas e outras tantas construídas com palha, assim como largas faixas de casas não caiadas ou muito enegrecidas, facilitando assim a composição das imagens das inúmeras habitações em ruínas presentes nos relatos dos viajantes. Contemplando esse trecho, seguindo o caminho desde Padre Faria, do outro lado do morro, Pohl destaca alguns elementos dessa paisagem, sendo especialmente interessante a menção às casas que dividiam espaço nessa ladeira e nas baixadas da cidade com as lavras de ouro, em uma sobreposição de funções nesses chãos (produção e reprodução da vida), particularmente relevante à sobrevivência da população mais pobre de Vila Rica:

vai este caminho até o Alto da Cruz, à igreja do Santo Rosário ... pela primeira vez, se pode enxergar a parte principal da cidade. Daqui também se inclina a cidade para baixo, e vielas tortuosas e mal calçadas conduzem a mais minas de ouro, instaladas entre edifícios, e até ao leito do Ribeirão Ouro Preto e, de lá, segundo parte da cidade, ou Antônio Dias. ${ }^{22}$

Walsh acentuaria em seu relato, é verdade que com certo exagero, a visão das áreas mais pobres de Vila Rica como um "montão de ruínas", ${ }^{23}$ e na leitura mais acurada de Saint-Hilaire também se marca a insistência de que a desolação acaba sempre por ser marca distintiva, especialmente nas entradas da cidade, anotando que:

apenas se deixa para trás Capão, a paisagem toma um ar de tristeza que conserva quase sempre até Vila Rica. Não se descobrem de todos os lados senão campos desertos, sem culturas e sem rebanhos. Se se avistam algumas casas, ordinariamente estão em ruínas. ${ }^{24}$

Um dos mais freqüentes acentos na visão dos viajantes vem mesmo desse impacto da forte transformação na paisagem natural. Quase todos fariam menção a esses "montes de cascalho" descartados das lavagens do ouro, como aos sulcos na terra e à ausência de cobertura vegetal em seus relatos, estando adjetivos como 'triste' e 'melancólico' mais diretamente associados a esses trechos. A ausência de vegetação natural é um ponto muito flagrante na iconografia para a cidade no período. Sylvio de Vasconcellos, ao analisar o tema, chama a atenção para a quase total ausência de árvores nas áreas urbanas retratadas, em quadro que só se alteraria já próximo do século XX. ${ }^{25}$ As paisagens pintadas por Rugendas para Vila Rica pouco servem para as considera- 
ções sobre a arquitetura e o casario, uma vez que foram tomadas a grande distância das áreas centrais do núcleo. (Figura 6) Não obstante, possibilitam, assim como o areal de Walsh, uma leitura dessas feridas cavadas na paisagem pelos trabalhos de mineração. (Figura 7) À exceção das plantações de araucá-

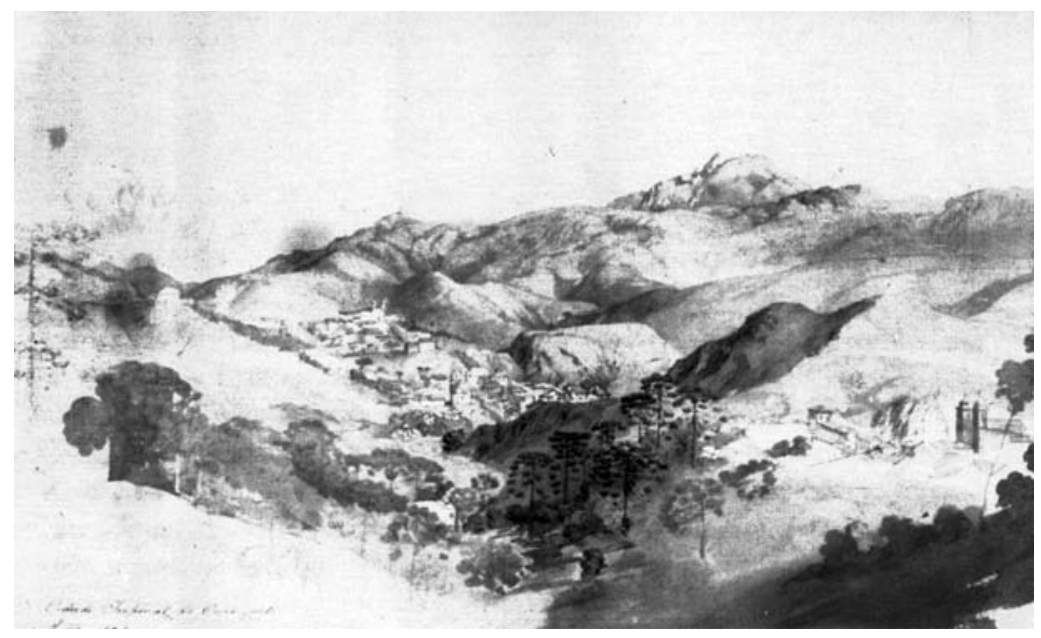

Figura 6 - Vista de Vila Rica (Cabeças e Ouro Preto), 1824 - Johann Moritz Rugendas.

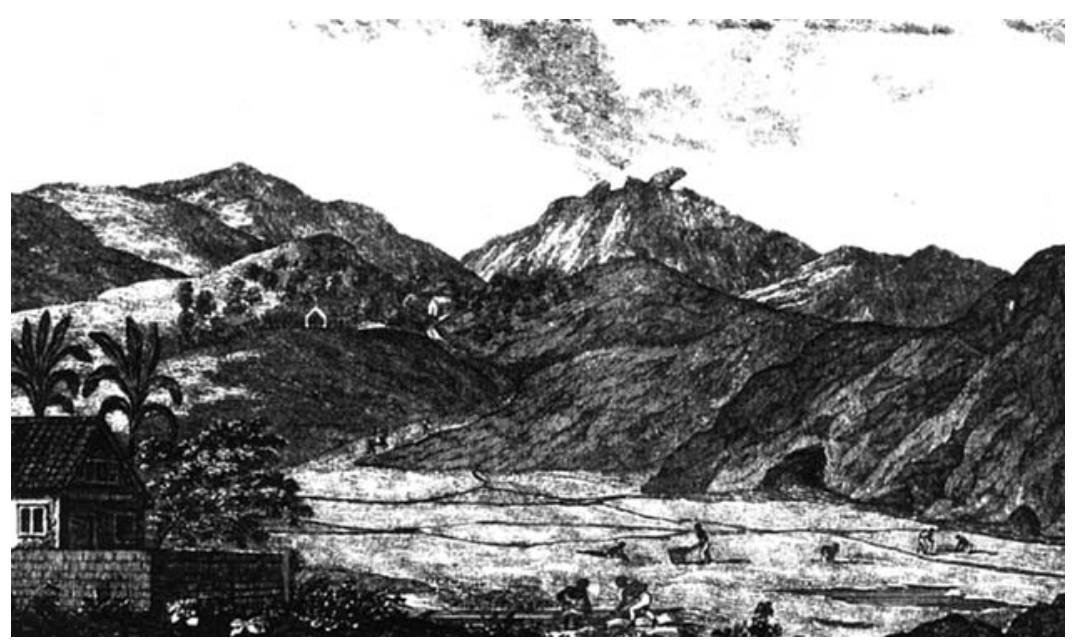

Figura 7 - Vista de Vila Rica (Ouro Preto), 1828 - Robert Walsh. Fonte: Robert Walsh. Notícias do Brasil. Belo Horizonte: Itatiaia; São Paulo: Edusp, 1985. v.2. 
rias no morro das Cabeças, anotadas por vários viajantes, a ausência das árvores no conjunto visual é também flagrante, mesmo com todas as ressalvas do cuidado de se considerar as características originais dessa vegetação de altitude.

A natureza primeira do nascimento urbano das Minas, pela sobreposição dos espaços de 'produção' e 'reprodução', deixaria por muito tempo marcadas essas faces da mineração mesmo nas áreas mais habitadas. ${ }^{26}$ Ao começo do século XIX, para além da atividade dos faiscadores que teimavam com a sorte nos cursos d'água, via-se especialmente nas minas que se mantiveram ativas nos morros em torno da cidade a força da mineração na transformação do espaço. A mina do coronel José Veloso do Carmo é bom exemplo desse panorama. Várias décadas minerando a 'talha aberta' no morro das Cabeças fizeram transformar vigorosamente aquele espaço. Spix e Martius ao visitar a mina narram a paisagem "ao longo de um profundo fosso, para uma garganta de rochas nuas que, cheia de fragmentos de pedras e de contornos irregularmente partidos, dava a impressão da mais selvagem destruição".27

$\mathrm{Na}$ leitura dos relatos desses viajantes fica patente a transformação na paisagem natural de Vila Rica e a sua retração da vitalidade urbana, diretamente associada às perdas populacionais, e amplamente articulada em um processo de retração da economia mineradora, o que abre espaço para se perguntar sobre possíveis transferências populacionais entre o cenário 'decadente’ de Vila Rica e o 'florescente' de São João no período, o que serve como uma indagação preliminar à análise específica dos dados populacionais na parte final deste artigo. Mas, a despeito desses deslocamentos sugeridos, sabe-se que as centralidades construídas ao longo do século XVIII ainda fariam Vila Rica avançar sua posição de lugar central no século XIX. ${ }^{28}$ Isso tanto no que diz respeito ao aspecto político, com amplo espectro de funções públicas e todas as mais convergências a partir da centralidade do poder associadas, como também, e especialmente, em relação ao comércio que articulava a Vila Rica partes distantes do território mineiro, e fazia recrudescer, ainda naquele momento do século XIX, a importância da cidade. Rugendas anota a exportação de ouro e pedras preciosas a partir da cidade, mas insiste em que a pauta era muito mais ampla, com tropas continuamente chegando e partindo, uma vez que "Vila Rica é o principal mercado da província". 29 Spix e Martius também insistem nesse ponto, ponderando com detalhes essas relações e flagrando a proeminência de uma bem tramada estrutura de serviços e comércio ${ }^{30}$ que, a despeito das perdas populacionais, ainda representava um panorama destacado dentro das Minas. Ao apresentar a cidade, insistem em que "quase todos os ofícios são praticados aqui”, e também na existência de uma "fábrica de pól- 
vora, uma de chapéus de feltro e outra de louça de barro" na região. Mas especialmente argumentam a importância de Vila Rica como entreposto de comércio e negócios, com todas as regiões de Minas, e com as outras províncias, dizendo que "entre todas as cidades no interior do Brasil, nenhuma tem comércio tão animado como Vila Rica". ${ }^{31}$

A estes recortes da paisagem entre Vila Rica e São João del Rey, que sugerem ritmos de retração ou florescência do urbano e respondem de forma direta ao crescimento ou retração populacional, a análise de um conjunto de dados demográficos na busca de evidências de movimentos internos da população nas Minas ajuda a desenhar um quadro mais circunstanciado das dinâmicas demográfico-espaciais no período.

\section{DINÂMICAS DEMOGRÁFICO-ESPACIAIS}

Minas encerra o século XVIII como a capitania mais populosa da América portuguesa, e avança pelo século XIX sustentando essa posição, o que acabou por ser muitos anos depois uma evidência incômoda às observações historiográficas de uma prolongada e vigorosa decadência econômica da capitania após o tempo do ouro. As revisões a essa perspectiva encontraram mais recentemente formulações muito bem estabelecidas e corroboradas, com farta base empírica, solapando a ótica da simples decadência econômica. O destaque ao tamanho da população de Minas na virada para o século XIX e sua manutenção de altas taxas de crescimento nesse século introduzem, não obstante, um tema complementar a essas lições apropriadas a partir das paisagens descritas pelos viajantes, e que diz respeito às voltas internas da população mineira do final do século XVIII para o início do XIX, pondo em forte evidência a nova organização regional da economia no território. Como grande pano de fundo subsiste um processo ampliado de ruralização, o que não implica o desaparecimento ou a retração absoluta dos núcleos urbanos, que em algumas áreas encontram mesmo, por essa época, o seu maior desenvolvimento. Trata-se, entretanto, de ver como surge uma feição própria do espaço em correspondência aos processos em curso na base produtiva. Assume especial relevo, assim, na questão espacial, o substantivo desenvolvimento da agropecuária na primeira metade do século XIX, mormente em áreas que já se destacavam nessas atividades desde a primeira metade do século XVIII.

Em outros termos, diz-se de um processo de ruralização em que, especialmente ao sul do território mineiro, predominaram as propriedades não 
muito extensas, nos moldes de uma produção "mercantil de subsistência", como a chamou Robert Slenes, ${ }^{32}$ sendo o comércio desses gêneros de abastecimento diretamente beneficiado por uma forte expansão do mercado a partir de 1808, o que acaba também por favorecer o incremento de alguns núcleos urbanos na posição de entrepostos comerciais e centro de negócios.

O movimento da população na primeira metade do século XIX dá números expressivos desse quadro geral. A população total de Minas Gerais sustenta um crescimento substantivo desde o final do século XVIII, passando de 319.769 habitantes, ou 341.869 no ajuste procedido por Laird Bergad, em 1776, ${ }^{33}$ para 694.768 em 1835 (Tabela 1). Interpondo-se aí os dados de 1808 e os coligidos por Cunha Matos para algo como $1820,{ }^{34}$ pode-se perceber mes-

\section{Tabela 1}

Minas - população das comarcas entre 1776 e 1835

\begin{tabular}{|c|c|c|c|c|c|c|c|c|c|}
\hline \multirow[t]{2}{*}{ Comarca } & \multicolumn{9}{|c|}{ População } \\
\hline & $1776[1]$ & $\%$ & $1776[2]$ & $\%$ & 1808 & $\%$ & c. 1820 & $\%$ & 1835 \\
\hline Ouro Preto & 78.618 & 24,59 & 78.618 & 23,00 & 72.286 & 16,69 & 71.796 & 13,02 & $84.376 \quad 12,14$ \\
\hline Sabará* & 99.576 & 31,14 & 99.576 & 29,13 & 135.920 & $31,39 \quad 1$ & 142.840 & 25,91 & $189.785 \quad 27,32$ \\
\hline Serro Frio & 58.794 & 18,39 & 80.894 & 23,66 & 69.974 & 16,16 & 99.919 & 18,12 & $106.112 \quad 15,27$ \\
\hline Rio das Mortes & 82.781 & 25,89 & 82.781 & 24,21 & 154.869 & $35,76 \quad 2$ & 236.819 & 42,95 & $314.495 \quad 45,27$ \\
\hline Total & 319.769 & 100,00 & $341.869 \quad 1$ & 100,00 & 433.049 & 100,005 & 551.374 & 100,00 & $694.768100,00$ \\
\hline \multicolumn{10}{|c|}{ Crescimento anual } \\
\hline & \multicolumn{2}{|c|}{$1776[1]-1808$} & $1776[2]-1808$ & \multicolumn{2}{|c|}{$\begin{array}{lll}3808-1820 & 1\end{array}$} & $1820-1835$ & \multicolumn{2}{|c|}{$5 \quad 1776[1]-1835$} & $1776[2]-1835$ \\
\hline Ouro Preto & $-0,26$ & & $-0,26$ & \multicolumn{2}{|c|}{$-0,06$} & 1,08 & \multicolumn{2}{|r|}{0,12} & 0,12 \\
\hline Sabará* & 0,97 & & 0,97 & \multicolumn{2}{|c|}{0,41} & 1,89 & \multicolumn{2}{|r|}{1,09} & 1,09 \\
\hline Serro Frio & \multicolumn{2}{|l|}{0,54} & $-0,45$ & \multicolumn{2}{|c|}{2,97} & 0,40 & \multicolumn{2}{|r|}{1,00} & 0,46 \\
\hline Rio das Mortes & \multicolumn{2}{|l|}{1,96} & 1,96 & \multicolumn{2}{|c|}{3,54} & 1,89 & \multicolumn{2}{|r|}{2,26} & 2,26 \\
\hline Total & \multicolumn{2}{|l|}{0,95} & 0,74 & \multicolumn{2}{|c|}{2,01} & 1,56 & \multicolumn{2}{|r|}{1,32} & 1,21 \\
\hline
\end{tabular}

*inclui valores referentes à comarca de Paracatu.

Fontes: RAPM, Ouro Preto (II, v.3), 1897, p.511; MATOS, Raimundo José da Cunha. Corografia..., v.1, p.89-216; MARTINS, Maria do C. S. "Revisitando a província: comarcas, termos, distritos e população de Minas Gerais em 1833-35”. In: 20 anos do Seminário sobre a Economia Mineira, v.II. Belo Horizonte: Cedeplar, 2002; BERGAD, Laird W. Slavery and the Demographic..., p.230-1. 
mo que este crescimento que ia arrefecendo no final do século XVIII se mostra mais acelerado no XIX, o que fica mais explícito ainda se forem colocados em perspectiva os dados para a população total desde as estimativas para a primeira metade do século XVIII até o censo provincial de 1872 . O quadro que se apresenta é o de um substantivo crescimento da população nas décadas intermediárias do século XVIII, sofrendo um grande abalo nesses níveis entre os últimos anos do século XVIII e os primeiros do XIX — como função direta do arrefecimento da economia que por essa época se fez mais evidente - , logo depois retomando com vigor as taxas de crescimento populacional, em conjuntura na qual se destaca fortemente a participação relativa da comarca do Rio das Mortes (Tabela 2). A leitura de tão ampliado período, é bom que se diga, não deixa de apresentar problemas consideráveis, no entanto é mais importante a oportunidade de contemplar tendências gerais no crescimento demográfico em Minas, sobremaneira interessantes para a compreensão dos ritmos do desenvolvimento das Minas.

\section{Tabela 2}

Minas - população entre 1721 e 1872

\begin{tabular}{lccccccccc}
\hline Ano & c.1721 & $1776[1]$ & $1776[2]$ & 1786 & 1808 & c.1820 & 1835 & 1855 & 1872 \\
\hline $\begin{array}{l}\text { População total } \\
\begin{array}{l}\text { Crescimento } \\
\text { anual }\end{array}\end{array}$ & 90.160 & 319.769 & 341.869 & 362.847 & 433.049 & 551.374 & 669.603 & 1.304 .007 & 2.041 .607 \\
\hline
\end{tabular}

Fontes: RAPM, Ouro Preto (II, v.3), 1897, p.511; RAPM, Belo Horizonte (IV, v.2), 1899, p.294-6; MATOS, Raimundo J. da C. Corografia..., v.1, p.89-216; MARTINS, Maria do C. S. “Revisitando a província...”, p.22-9; BOTELHO, Tarcísio R. "População e escravidão nas Minas Gerais, c.1720”. Anais eletrônicos do 120 Encontro da ABEP. Belo Horizonte, 2000, p.14-8; BERGAD, Laird W. Slavery and the Demographic..., p.230-7.

As voltas internas da população, entretanto, é que revelam as facetas mais interessantes desse crescimento demográfico. De acordo com a Tabela 1, fica evidente que a comarca de Ouro Preto perde progressivamente seu nível de participação relativa no conjunto da população de Minas Gerais, o que toma forma por conta de taxas de crescimento bem abaixo da média da capitania/província, especialmente entre 1776 e 1820, quando atinge valores negativos. Nada muito diferente pode-se dizer da comarca de Sabará, que cresce pouco entre 1776 e 1820. Mesmo os números mais expressivos de seu crescimento a partir de 1820 devem-se à região de Paracatu e aos julgados de Araxá e Desemboque, agregados à comarca de Sabará tanto nos dados de 1776 como nos do século XIX, para efeito de identidade comparativa entre os dados. ${ }^{36}$

A comarca do Serro Frio tem comportamento bastante diferenciado se 
usados os dados originais de 1776 ou os apresentados por Bergad, uma vez que os ajuste realizados por esse autor se referem à participação de Minas Novas na população total da comarca. Na primeira opção, verifica-se um crescimento levemente positivo tanto entre 1776 e 1808 como em 1820 e 1835 , cabendo aos anos entre 1808 e 1820 uma taxa especialmente alta; não obstante, sua participação relativa no conjunto da população permanece relativamente estável em todo o período. Considerando a segunda opção, a alteração nos dados de 1776 suscita perdas populacionais entre esse ano e o de 1808, refletindo-se também em sua participação relativa no total da população.

Mas é mesmo o eixo sul do território que responde mais diretamente pelo crescimento da população mineira, sustentando altas taxas de crescimento ao longo de todo o período analisado. A população da comarca do Rio das Mortes passa assim de 82.781 habitantes em 1776 (25,89\% da população total da capitania) para 314.495 em 1835 (45,27\%), o que marca taxas de crescimento anual bem acima da média da capitania/província. É interessante verificar que o grande peso desse crescimento estaria localizado entre $1808 \mathrm{e}$ 1820, exatamente no período em que se dá uma vigorosa expansão do setor de exportação de gêneros de abastecimento para a praça do Rio de Janeiro a partir da transferência da Corte, em 1808. Sem dúvida é eloqüente esse crescimento representando um evidente rearranjo na distribuição populacional em Minas no período, passando a participação relativa dessa comarca de pouco mais de um quarto em 1776 para quase metade da população total em 1835. Esses dados dão espaço a considerações não só sobre a proeminência econômica da região - a responsável direta por esse crescimento demográfico, embasado em um ampliado processo de dinamização da agropecuária e ocupação de áreas rurais -, que teria como uma de suas resultantes uma entrada acentuada de escravos africanos ${ }^{37}$ mas também sobre a força de atração populacional que exerceria o sul de Minas na população de livres e forros de outras regiões.

Uma vez que o foco da discussão aqui empreendida está nas regiões de Vila Rica e São João del Rey, vale olhar de forma mais atenta os dados específicos da distribuição interna da população nessas duas comarcas, representados nas Tabelas 3 e 4. Para a primeira o que mais salta aos olhos é a perda persistente de população do termo de Ouro Preto, em processo continuado desde o final do século XVIII, apresentando substantivas taxas negativas no seu crescimento anual que bem se agravam entre 1820 e 1835, fazendo a vila e seus distritos perderem quase metade de sua população no período. É o termo de Mariana que no mesmo período sustenta um crescimento considerável, sendo o responsável 
pelo aumento populacional da comarca. É bom que se note, entretanto, que esse crescimento do termo de Mariana não se concentrou na região dos antigos centros mineradores, sendo as áreas de expansão a leste e um pouco mais ao sul, nas imediações do rio Pomba e no conjunto das terras de maior adensamento rural no vale do rio Doce, as maiores responsáveis por esses números.

Tabela 3

Comarca de Ouro Preto

\begin{tabular}{lccccccccc}
\hline Termo & População & & & & \multicolumn{5}{c}{ Crescimento anual } \\
\hline & 1808 & $\%$ & c. 1820 & $\%$ & 1835 & $\%$ & $1808-1820$ & $1820-1835$ & $1808-1835$ \\
\hline Ouro Preto & 22.222 & 30,74 & 20.126 & 28,07 & 11.206 & 13,28 & $-0,83$ & $-3,9$ & $-2,54$ \\
Mariana & 50.064 & 69,26 & 51.570 & 71,93 & 73.170 & 86,72 & 0,25 & 2,33 & 1,41 \\
Total & 72.286 & 100 & 71.696 & 100 & 84.376 & 100 & $-0,07$ & 1,09 & 0,57 \\
\hline
\end{tabular}

Fontes: MATOS, Raimundo J. da C. Corografia..., v.1, p.89-216; MARTINS, Maria do C. S. "Revisitando a província...", p.22-9; BERGAD, Laird W.. Slavery and the Demographic..., p.230-1.

Tabela 4

Comarca do Rio das Mortes

\begin{tabular}{lccccccccc}
\hline Termo & \multicolumn{1}{c}{ População } & & & & \multicolumn{5}{c}{ Crescimento anual } \\
\hline & 1808 & $\%$ & c.1820 & $\%$ & 1835 & $\%$ & $1808-1820$ & $1820-1835$ & $1808-1835$ \\
\hline São João del Rey 25.441 & 16,43 & 44.354 & 18,73 & 44.899 & 14,28 & 4,63 & 0,08 & 2,1 \\
São José del Rey & 21.488 & 13,87 & 17.170 & 7,25 & 36.608 & 11,64 & $-1,87$ & 5,05 & 1,97 \\
Barbacena & 16.237 & 10,48 & 29.155 & 12,31 & 36.361 & 11,56 & 4,88 & 1,47 & 2,99 \\
Campanha & $55.375^{*}$ & 35,76 & 49.246 & 20,79 & 64.543 & 20,52 & & 1,8 & 0,57 \\
Baependi & & & 30.902 & 13,05 & 45.373 & 14,43 & & 2,56 & \\
Jacuí & & & 15.229 & 6,43 & 32.545 & 10,35 & & 5,06 & \\
Tamanduá & 16.030 & 10,35 & 28.029 & 11,84 & 29.441 & 9,36 & 4,66 & 0,33 & 2,25 \\
Queluz & 20.298 & 13,11 & 22.734 & 9,6 & 24.725 & 7,86 & 0,94 & 0,56 & 0,73 \\
Total & 154.869 & 100,00 & 236.819 & 100,00 & 314.495 & 100,00 & 3,54 & 1,89 & 2,62 \\
\hline
\end{tabular}

* Inclui os totais relativos a Baependi e Jacuí.

Fontes: MATOS, Raimundo J. da C. Corografia..., v.1, p.89-216; MARTINS, Maria do C. S. "Revisitando a província...”, p.22-9; BERGAD, Laird W. Slavery and the Demographic..., p.230-1. 
A comarca do Rio das Mortes (Tabela 4), por sua vez, apresenta um quadro muito diverso. Ao que parece, o crescimento a altas taxas que sustentava desde o final do século XVIII já atingia com intensidade distinta algumas partes da região pela altura de 1835 . Entre 1820 e 1835, o que se nota é uma relativa estagnação da região de São João, que foi a que a princípio respondeu por grande parte do desenvolvimento do eixo sul do território mineiro, com taxas especialmente vigorosas entre 1808 e 1820, mas que não obstante sua destacada posição comercial no período, não deixava de ser uma área atingida pelas mesmas conjunturas que tocavam os antigos núcleos mineradores. Isso é especialmente verdade para a vila de São João e não necessariamente para os outros distritos do termo. Ao mesmo tempo a vila perdeu a centralidade quase absoluta como entreposto dos negócios da região, fato especialmente observado no crescimento dos fluxos de comércio da comarca por vias que não tinham São João no trajeto, como no primitivo caminho que passava pelo registro da Mantiqueira, e logo depois na muito freqüentada estrada do Pi$\mathrm{cu}$, ligando a região de Baependi ao Rio de Janeiro pelo encontro com a rota proveniente de São Paulo. ${ }^{37}$ Queluz, por sua vez, sofre essa retração pertinente às áreas mais antigas de mineração. apresentando uma baixa taxa de crescimento no período, não obstante estampar algum aumento populacional, todavia bem focado em alguns de seus distritos. ${ }^{39} \mathrm{O}$ maior crescimento populacional, entretanto, estaria localizado em outras áreas, responsáveis por expansões mais recentes das fronteiras rurais e que, indiretamente, sustentavam a centralidade, até mesmo, que a vila de São João gozava nas primeiras décadas do século XIX.

O termo de Campanha, que ainda crescia a taxas bastante significativas entre 1820 e 1835, concentrou entretanto seu maior crescimento anos antes, nos últimos anos do século XVIII, época em que é elevada à condição de vila (1798). Nos dados de 1808, tem-se agregada a Campanha a população referente ao que mais tarde seriam os termos de Jacuí e Baependi, ambas vilas criadas em 1814. Essas três áreas juntas deteriam 35,76 por cento da população total da comarca em 1808. Campanha, mesmo depois de perder esses dois territórios em 1814, ainda continua tendo a maior participação relativa na comarca, 20,79 por cento da população total em 1820 e 20,52 por cento em 1835. Os ritmos do crescimento nessas três áreas, que na virada do século compunham o grande termo de Campanha, são reveladores de uma dinâmica diferenciada na ocupação do sul de Minas. A princípio o crescimento se localizou em Campanha, depois se direcionando para outros pontos da região; ganha intensidade aí a ocupação do sudoeste, nas áreas próximas à nas- 
cente do rio Grande e onde se localiza Baependi, e o sudoeste, nas terras além do rio Sapucaí, onde está Jacuí. O termo de Jacuí mais que dobra sua população entre 1820 e 1835, passando de 15.229 habitantes para 32.545, imprimindo alta taxa de crescimento anual. Baependi, por sua vez, cresce em velocidade menor no período, mas em termos absolutos seria o segundo termo em números de habitantes em 1835.

Entre 1808 e 1820, o período mesmo de maior aceleração no aumento populacional da comarca, são especialmente altas as taxas de crescimento para as áreas de Tamanduá e Barbacena. Assim como em Campanha, é na virada do século que essas localidades são elevadas à condição de vila, respectivamente em 1789 e 1791. Ambas retrocederiam nesses ritmos demográficos no período de 1820 a 1835, especialmente o termo de Tamanduá.

O termo de São José del Rey registraria uma taxa negativa de crescimento entre 1808 e 1820, o que não obstante pode ser um problema na correspondência dos distritos de 1820 apresentados por Cunha Matos com os dados agregados para 1808, mas de toda forma aproxima as questões já aventadas sobre o arrefecimento dos antigos núcleos mineradores. Já para o período entre 1820 e 1835, a situação verificada é a de um crescimento muito acelerado, que pelo que foi possível verificar nos dados desagregados para 1820 e 1835 , não está localizada na área dos núcleos mineradores originais, sendo a região de Oliveira e imediações a principal responsável por esse aumento da população. Vale lembrar que o próprio Cunha Matos anotava à época em sua corografia histórica que "este arraial promete grande crescimento". ${ }^{40}$

O tema do crescimento acelerado de algumas regiões e do arrefecimento de outras, como também algumas inferências sobre fluxos de migração entre as regiões, pode ser mais bem abordado com o recurso a análises dos dados de distribuições etárias dos habitantes. Esse procedimento possibilita, mesmo que com os dados atinentes a um único ano, a captação de dinâmicas da população em períodos anteriores. ${ }^{41}$ Em suas análises populacionais de Vila Rica, Iraci del Nero Costa vale-se dessa ferramenta para argumentar sobre as perdas populacionais que a cidade sofria no começo do século XIX. Algumas variáveis demográficas se relacionam muito proximamente ao tema dessas perdas populacionais, que grosso modo podem ser associadas a fluxos de migrações internas no território mineiro. Ao caso dessa sociedade particular da passagem do século, pode-se entender que a maior propensão a migrar estaria no grupo dos homens, livres ou libertos, ${ }^{42}$ e que fossem ainda jovens e solteiros. Analisando a população a partir desses cortes, Iraci Costa constatou certo desequilíbrio entre a distribuição dos sexos na pirâmide etária dos livres e libertos, com valores sig- 
nificativamente menores de homens para algumas idades, o que ainda se agravaria mais se fosse considerada somente a população solteira. De acordo com a Tabela 5, pode-se inferir, na linha apontada pelo autor, que as pessoas entre 15 e 34 anos apresentam maior tendência para migrar, ${ }^{42}$ o que projeta esses resultados de 1804 para perdas ocorridas já desde os últimos anos do século XVIII. Comparando-se essas faixas etárias, verifica-se um desequilíbrio acentuado na razão de masculinidade, que, a despeito de já ser expressivo no conjunto da população, ainda se faz mais evidente nesses estratos.

Tabela 5

Ouro Preto - 1804 (livres e libertos)

\begin{tabular}{lccccc}
\hline & Homens & $\%$ & Mulheres & $\%$ & Total \\
\hline $0-4$ & 317 & 51 & 302 & 49 & 619 \\
$5-9$ & 341 & 48 & 363 & 52 & 704 \\
$10-14$ & 332 & 53 & 297 & 47 & 629 \\
$15-19$ & 207 & 43 & 270 & 57 & 477 \\
$20-24$ & 174 & 36 & 313 & 64 & 487 \\
$25-29$ & 173 & 36 & 307 & 64 & 480 \\
$30-34$ & 202 & 40 & 300 & 60 & 502 \\
$35-39$ & 153 & 46 & 182 & 54 & 335 \\
$40-44$ & 173 & 40 & 259 & 60 & 432 \\
$45-49$ & 107 & 49 & 112 & 51 & 219 \\
$50-54$ & 135 & 42 & 188 & 58 & 323 \\
$55-59$ & 72 & 48 & 78 & 52 & 150 \\
$60-64$ & 113 & 45 & 139 & 55 & 252 \\
$65-69$ & 36 & 40 & 55 & 60 & 91 \\
$70-.$. & 120 & 45 & 149 & 55 & 269 \\
Total & 2.655 & 44 & 3.314 & 56 & 5.969 \\
\hline
\end{tabular}

Fonte: COSTA, Iraci del N. da. Minas Gerais..., p.119.

A análise de um conjunto de dados relativo a Ouro Preto para o ano de 1838 (Tabela 6) mostra claramente como os efeitos de uma continuada perda de população entre os jovens livres do sexo masculino ao longo da primeira metade 
do século XIX faz espalhar mais uniformemente por toda a pirâmide (à exceção do grupo entre 0 a 15 anos) esse desequilíbrio, nas mesmas proporções que em 1804 só se verificava entre os mais jovens. Note-se, não obstante, que o mais contundente dado é mesmo que, em termos absolutos, a perda de população entre os livres, grande maioria na cidade, é extremamente acentuada, o que é uma diferença marcante em relação a outros núcleos que, mesmo sugerindo a partir desses desequilíbrios da razão de masculinidade certos movimentos populacionais, não chegam a afetar de forma tão veemente o seu crescimento total.

\section{Tabela 6}

Ouro Preto - 1838 (livres e libertos)

\begin{tabular}{lccccc}
\hline & Homens & $\%$ & Mulheres & $\%$ & Total \\
\hline $0-4$ & 153 & 52 & 144 & 48 & 297 \\
$5-9$ & 174 & 48 & 185 & 52 & 359 \\
$10-14$ & 123 & 44 & 156 & 56 & 279 \\
$15-19$ & 120 & 49 & 124 & 51 & 244 \\
$20-24$ & 94 & 36 & 165 & 64 & 259 \\
$25-29$ & 83 & 44 & 106 & 56 & 189 \\
$30-34$ & 95 & 41 & 134 & 59 & 229 \\
$35-39$ & 71 & 36 & 124 & 64 & 195 \\
$40-44$ & 71 & 40 & 105 & 60 & 176 \\
$45-49$ & 43 & 42 & 59 & 58 & 102 \\
$50-54$ & 68 & 41 & 96 & 59 & 164 \\
$55-59$ & 29 & 40 & 43 & 60 & 72 \\
$60-64$ & 42 & 36 & 76 & 64 & 118 \\
$65-69$ & 15 & 45 & 18 & 55 & 33 \\
$70-\ldots$ & 40 & 39 & 63 & 61 & 103 \\
Total & 1.221 & 43 & 1.598 & 57 & 2.819 \\
\hline
\end{tabular}

Fonte: APM - Listas nominativas de 1831-1832 e 1838-1840

(Banco de Dados do Núcleo de Pesquisa em História Econômica e Demográfica do Cedeplar/UFMG). 
Com base na análise de outros distritos da comarca de Ouro Preto, podese avaliar o ritmo variado desses movimentos populacionais que, como se viu, afetaram praticamente toda a comarca, estabelecendo-se por áreas com bases econômicas distintas. Ainda em referência a trabalhos de Iraci del Nero da Costa, vale o olhar rápido a dois outros distritos: Furquim e Nossa Senhora dos Remédios. O primeiro é uma localidade antiga, situada em área próxima a Mariana e de nascimento ligado às explorações auríferas; o segundo é área de ocupação mais recente, pertencente à paróquia de Barbacena. Furquim é tipificada por Iraci Costa no que diz respeito à sua estrutura populacional como uma região 'intermediária', querendo com isso referir-se à sobreposição com a base rural de atividades de mineração, comércio e serviços; em suas palavras: "Os habitantes de Furquim dedicavam-se, basicamente, à agricultura, à faiscação e à variada gama de atividades artesanais". ${ }^{44}$ A pirâmide etária para o ano de 1804 mostra um predomínio da população feminina entre os livres desde os 20 até os 60 anos, do que se infere que desde a penúltima década do século XVIII essa área marcava um processo relativamente acentuado de emigração de jovens do sexo masculino. Iraci Costa cruza aí os dados de estado matrimonial e demonstra que esse desequilíbrio da razão de masculinidade era maior ainda entre os solteiros (Tabela 7). ${ }^{45}$ Avaliando em conjuntos os dados recolhidos a partir das listas nominativas de 1831, verifica-se que, a despeito de o distrito apresentar um crescimento significativo de sua população no período, a tendência para a migração dos jovens do sexo masculino parece ainda marcada, muito embora já em um ritmo diverso do que se estampava no começo do século. O desequilíbrio maior se verifica, portanto, acima dos 50 anos, preservando números menos acentuados entre os $20 \mathrm{e}$ os 40. Essa estrutura populacional e econômica marcada pela sobreposição de atividades variadas em uma base agropecuária seria comum a diversos outros núcleos médios no período, e responsável pela sustentação de um crescimento populacional mesmo em face da retração de certas atividades tradicionais (Tabela 8).

O distrito de Nossa Senhora dos Remédios, por sua vez, apresenta um quadro um tanto diverso. Está localizado na porta de entrada para a região sul do território mineiro, e é descrito por Iraci Costa como área "rural de autoconsumo", em que a atividade que reúne a maioria dos habitantes é incisivamente a agricultura. Predominam aí famílias nucleares, com poucos escravos ou mesmo sem eles, ocupando-se incisivamente de produzir gêneros indispensáveis à própria manutenção. ${ }^{46}$ Essa fórmula bem pode ser generalizada a uma larga faixa dos pequenos distritos da região sul; todavia, não é de- 
Tabela 7

Forquim - 1804 (livres e libertos)

\begin{tabular}{lccccc}
\hline & Homens & $\%$ & Mulheres & $\%$ & Total \\
\hline $0-4$ & 73 & 56 & 58 & 44 & 131 \\
$5-9$ & 78 & 55 & 65 & 45 & 143 \\
$10-14$ & 74 & 59 & 51 & 41 & 125 \\
$15-19$ & 51 & 50 & 50 & 50 & 101 \\
$20-24$ & 51 & 46 & 59 & 54 & 110 \\
$25-29$ & 26 & 29 & 64 & 71 & 90 \\
$30-34$ & 32 & 42 & 45 & 58 & 77 \\
$35-39$ & 30 & 45 & 36 & 55 & 66 \\
$40-44$ & 35 & 45 & 43 & 55 & 78 \\
$45-49$ & 25 & 37 & 43 & 63 & 68 \\
$50-54$ & 23 & 34 & 45 & 66 & 68 \\
$55-59$ & 18 & 43 & 24 & 57 & 42 \\
$60-64$ & 30 & 49 & 31 & 51 & 61 \\
$65-69$ & 13 & 76 & 4 & 24 & 17 \\
$70-.$. & 36 & 56 & 28 & 44 & 64 \\
Total & 595 & 48 & 646 & 52 & 1.241 \\
\hline
\end{tabular}

Fonte: COSTA, Iraci del N. da. Minas Gerais..., p.123.

mais ressaltar que as pequenas propriedades não foram regra geral, existindo muitas fazendas de grande porte em algumas regiões. A distribuição etária da população de Remédios apresenta algumas notas interessantes. Com base nos dados para 1804, vê-se reforçada a mesma tendência para emigração dos homens entre 20 e 40 anos; não obstante, para o grupo acima dos 55 anos verifica-se uma clara maioria de elementos do sexo masculino, o que indica a atração populacional do distrito no último quartel do século XVIII, confirmando a feição de uma área de ocupação recente (Tabela 9). Essa preponderância de elementos do sexo masculino, indicando o nível de atração populacional de uma região, é um acento característico de diversas áreas no eixo sul do território mineiro, possibilitando bases mais consistentes para se verificar os focos do crescimento populacional na comarca do Rio das Mortes, pondo em 
Tabela 8

Forquim - 1831 (livres e libertos)

\begin{tabular}{lccccc}
\hline & Homens & $\%$ & Mulheres & $\%$ & Total \\
\hline $0-4$ & 39 & 48 & 43 & 52 & 82 \\
$5-9$ & 65 & 55 & 53 & 45 & 118 \\
$10-14$ & 41 & 51 & 40 & 49 & 81 \\
$15-19$ & 47 & 48 & 50 & 52 & 97 \\
$20-24$ & 35 & 39 & 54 & 61 & 89 \\
$25-29$ & 28 & 41 & 41 & 59 & 69 \\
$30-34$ & 28 & 42 & 38 & 58 & 66 \\
$35-39$ & 16 & 43 & 21 & 57 & 37 \\
$40-44$ & 32 & 41 & 46 & 59 & 78 \\
$45-49$ & 23 & 53 & 20 & 47 & 43 \\
$50-54$ & 27 & 39 & 42 & 61 & 69 \\
$55-59$ & 12 & 39 & 19 & 61 & 31 \\
$60-64$ & 14 & 37 & 24 & 63 & 38 \\
$65-69$ & 6 & 40 & 9 & 60 & 15 \\
$70-.$. & 8 & 27 & 22 & 73 & 30 \\
Total & 421 & 45 & 522 & 55 & 943 \\
\hline
\end{tabular}

Fonte: APM - Listas nominativas de 1831-1832 e 1838-1840.

destaque aí a mobilidade da população livre ou forra nesse momento de reorientações na economia mineira.

Pontos diferentes da região sul partilharam esse movimento de expansão das fronteiras rurais na primeira metade do século XIX e tiveram assim dinâmicas populacionais parecidas. O sudoeste do território, responsável por um dos mais acentuados níveis de crescimento da comarca no período, é o que melhor corrobora essa perspectiva. O distrito de Cabo Verde, por exemplo, que está situado em uma área mais ao sul da vila de São Carlos do Jacuí, aumenta sua população de 1.972 habitantes em 1820 ou pouco antes, para 6.414 em 1835. Em sua pirâmide etária em 1831 verifica-se um forte desequilíbrio em favor da população masculina a partir dos 25 anos, deixando espaço para a inferência de uma continuada entrada de população livre desde a 
Tabela 9

Remédios - 1804 (livres e libertos)

\begin{tabular}{lccccc}
\hline & Homens & $\%$ & Mulheres & $\%$ & Total \\
\hline $0-4$ & 52 & 49 & 54 & 51 & 106 \\
$5-9$ & 53 & 50 & 54 & 50 & 107 \\
$10-14$ & 51 & 57 & 39 & 43 & 90 \\
$15-19$ & 30 & 41 & 43 & 59 & 73 \\
$20-24$ & 27 & 44 & 35 & 56 & 62 \\
$25-29$ & 19 & 40 & 28 & 60 & 47 \\
$30-34$ & 16 & 44 & 20 & 56 & 36 \\
$35-39$ & 19 & 41 & 27 & 59 & 46 \\
$40-44$ & 20 & 50 & 20 & 50 & 40 \\
$45-49$ & 14 & 52 & 13 & 48 & 27 \\
$50-54$ & 19 & 53 & 17 & 47 & 36 \\
$55-59$ & 10 & 77 & 3 & 23 & 13 \\
$60-64$ & 10 & 56 & 8 & 44 & 18 \\
$65-69$ & 3 & 100 & 0 & 0 & 3 \\
$70-\ldots$ & 12 & 80 & 3 & 20 & 15 \\
Total & 355 & 49 & 364 & 51 & 719 \\
\hline
\end{tabular}

Fonte: COSTA, Iraci del N. da. Minas Gerais..., p.132.

virada do século (Tabela 10). No outro extremo do território, já apontando para o crescimento futuro que teria a região da Zona da Mata no território mineiro, o distrito de São João Nepomuceno, área de ocupação mais recente, revela um processo que pela década de 1830 ganhava mais força. O desequilíbrio em favor da população masculina é assim mais marcado entre os 25 e os 50 anos (Tabela 11). Mais ao centro da região sul, abaixo de Baependi e contíguo às áreas que se desenvolviam em função dos fluxos de comércio na estrada do Picu, o distrito de Espírito Santo do Cunquibus, mais tarde Cristina, é outro bom exemplo desse crescimento. Aumentando sua população de 918 habitantes por volta de 1820 para 2.357 em 1835, e com uma distribuição etária que em 1831 evidencia um número substantivamente maior de homens 
Tabela 10

Cabo Verde - 1831 (livres e libertos)

\begin{tabular}{lccccc}
\hline & Homens & $\%$ & Mulheres & $\%$ & Total \\
\hline $0-4$ & 195 & 54 & 169 & 46 & 364 \\
$5-9$ & 206 & 51 & 200 & 49 & 406 \\
$10-14$ & 187 & 53 & 163 & 47 & 350 \\
$15-19$ & 95 & 42 & 133 & 58 & 228 \\
$20-24$ & 136 & 48 & 147 & 52 & 283 \\
$25-29$ & 105 & 55 & 85 & 45 & 190 \\
$30-34$ & 93 & 48 & 101 & 52 & 194 \\
$35-39$ & 58 & 55 & 48 & 45 & 106 \\
$40-44$ & 81 & 56 & 64 & 44 & 145 \\
$45-49$ & 27 & 42 & 37 & 58 & 64 \\
$50-54$ & 67 & 59 & 47 & 41 & 114 \\
$55-59$ & 26 & 59 & 18 & 41 & 44 \\
$60-64$ & 45 & 68 & 21 & 32 & 66 \\
$65-69$ & 13 & 76 & 4 & 24 & 17 \\
$70-\ldots$ & 14 & 52 & 13 & 48 & 27 \\
Total & 1.348 & 52 & 1.250 & 48 & 2.598 \\
\hline
\end{tabular}

Fonte: APM - Listas nominativas de 1831-1832 e 1838-1840.

entre 15 e 30 anos e entre 40 e 60, afina-se com a tendência geral de crescimento e atração populacional do sul de Minas no período (Tabela 12).

O que se pode argumentar a partir da distribuição etária para São João del Rey em 1840, entretanto, não parece reforçar esse crescimento da região sul. É bem verdade que o fato de esta análise se valer de um conjunto de dados para meados do século XIX impossibilita considerações acerca do movimento da população no final do século XVIII, que a princípio seria de maior interesse aqui, sendo essa a época em que, ao que outras fontes, como os próprios relatos de viagem, indicam, deu-se certo impulso à vitalidade urbana na cidade. Não obstante, o exercício de rastrear nas dinâmicas cristalizadas nos dados de 1840 alguns movimentos da primeira metade do século XIX já 
Tabela 11

São João Nepomuceno - 1831 (livres e libertos)

\begin{tabular}{lccccc}
\hline & Homens & $\%$ & Mulheres & $\%$ & Total \\
\hline $0-4$ & 111 & 47 & 127 & 53 & 238 \\
$5-9$ & 121 & 51 & 118 & 49 & 239 \\
$10-14$ & 103 & 54 & 86 & 46 & 189 \\
$15-19$ & 72 & 54 & 61 & 46 & 133 \\
$20-24$ & 74 & 51 & 71 & 49 & 145 \\
$25-29$ & 51 & 59 & 36 & 41 & 87 \\
$30-34$ & 42 & 47 & 48 & 53 & 90 \\
$35-39$ & 35 & 49 & 37 & 51 & 72 \\
$40-44$ & 56 & 58 & 41 & 42 & 97 \\
$45-49$ & 19 & 70 & 8 & 30 & 27 \\
$50-54$ & 25 & 53 & 22 & 47 & 47 \\
$55-59$ & 15 & 71 & 6 & 29 & 21 \\
$60-64$ & 13 & 50 & 13 & 50 & 26 \\
$65-69$ & 7 & 70 & 3 & 30 & 10 \\
$70-\ldots$ & 5 & 50 & 5 & 50 & 10 \\
Total & 749 & 52 & 682 & 48 & 1431 \\
\hline
\end{tabular}

Fonte: APM - Listas nominativas de 1831-1832 e 1838-1840.

é de grande interesse. A conclusão principal vai contra primeiras expectativas, mas acaba por ressaltar o argumento geral da ruralização. Vê-se que São João del Rey, a despeito de ter efetivamente vivenciado um processo de desenvolvimento urbano a partir do impulso proporcionado por sua posição comercial nas primeiras décadas do século XIX, não se conforma em um centro de atração populacional, tal qual o foi por conta de ouro em anos já muito distantes. A idéia central que permeia essa constatação é que a atração populacional na primeira metade do século XIX em Minas relaciona-se incisivamente às áreas de expansão agropecuária. Os núcleos urbanos, mesmo que florescentes por conta de uma posição estratégica de entrepostos comerciais, não representam foco para a migração senão de alguns grupos profissionais, como os artífices.

A questão das cidades vazias durante toda a semana, povoadas somente por 
Tabela 12

Espírito Santo dos Cunquibus - 1831 (livres e libertos)

\begin{tabular}{lccccc}
\hline & Homens & $\%$ & Mulheres & $\%$ & Total \\
\hline $0-4$ & 111 & 47 & 127 & 53 & 238 \\
$5-9$ & 121 & 51 & 118 & 49 & 239 \\
$10-14$ & 103 & 54 & 86 & 46 & 189 \\
$15-19$ & 72 & 54 & 61 & 46 & 133 \\
$20-24$ & 74 & 51 & 71 & 49 & 145 \\
$25-29$ & 51 & 59 & 36 & 41 & 87 \\
$30-34$ & 42 & 47 & 48 & 53 & 90 \\
$35-39$ & 35 & 49 & 37 & 51 & 72 \\
$40-44$ & 56 & 58 & 41 & 42 & 97 \\
$45-49$ & 19 & 70 & 8 & 30 & 27 \\
$50-54$ & 25 & 53 & 22 & 47 & 47 \\
$55-59$ & 15 & 71 & 6 & 29 & 21 \\
$60-64$ & 13 & 50 & 13 & 50 & 26 \\
$65-69$ & 7 & 70 & 3 & 30 & 10 \\
$70-\ldots$ & 5 & 50 & 5 & 50 & 10 \\
Total & 749 & 52 & 682 & 48 & 1.431 \\
\hline
\end{tabular}

Fonte: APM - Listas nominativas de 1831-1832 e 1838-1840.

artífices, comerciantes e prostitutas, repetidas vezes abordada pelos viajantes estrangeiros, é faceta desse movimento amplo que põe em destaque o rural, com acentos muito diversos do tempo em que a base mineradora da economia fazia sobrepor relações de produção no espaço urbano, bem como um grau de dependência cotidiana inúmeras vezes maior do que o que se verificaria em uma economia baseada na marcantilização da produção de gêneros de subsistência. Os dados relativos a São João del Rey revelam um desequilíbrio pronunciado entre a população de homens e mulheres, que se estendia por praticamente toda a pirâmide a partir dos 25 anos (Tabela 13). Para esse processo, que não difere em nada do de outros antigos núcleos mineradores, é possível avaliar que, uma vez que os homens entre 20 e 30 anos são o grupo com maior tendência a migrar, a cidade já era atingida por uma saída persistente de população desde ao menos o final da primeira década do século XIX. 
Tabela 13

São João del Rey - 1840 (livres e libertos)

\begin{tabular}{lccccc}
\hline & Homens & $\%$ & Mulheres & $\%$ & Total \\
\hline $0-4$ & 90 & 58 & 66 & 42 & 156 \\
$5-9$ & 103 & 49 & 107 & 51 & 210 \\
$10-14$ & 104 & 51 & 98 & 49 & 202 \\
$15-19$ & 68 & 44 & 88 & 56 & 156 \\
$20-24$ & 60 & 48 & 65 & 52 & 125 \\
$25-29$ & 45 & 40 & 67 & 60 & 112 \\
$30-34$ & 31 & 36 & 56 & 64 & 87 \\
$35-39$ & 43 & 51 & 41 & 49 & 84 \\
$40-44$ & 33 & 35 & 62 & 65 & 95 \\
$45-49$ & 31 & 48 & 33 & 52 & 64 \\
$50-54$ & 42 & 49 & 44 & 51 & 86 \\
$55-59$ & 23 & 68 & 11 & 32 & 34 \\
$60-64$ & 18 & 42 & 25 & 58 & 43 \\
$65-69$ & 10 & 38 & 16 & 62 & 26 \\
$70-\ldots$ & 19 & 40 & 28 & 60 & 47 \\
Total & 720 & 47 & 807 & 53 & 1.527 \\
\hline
\end{tabular}

Fonte: APM - Listas nominativas de 1831-1832 e 1838-1840.

CONSIDERAÇÃO FINAL

A retração do elemento urbano, e incisivamente das relações sociais e culturais de alguma forma dependentes dessa formação espacial, é processo que atinge o conjunto das Minas no século XIX, e não somente uma área, mesmo que sejam bastante óbvios seus alvos prediletos. A posição de São João del Rey adquire um relevo interessante não por conta de qualquer imunidade ao processo de arrefecimento do ritmo de desenvolvimento dos espaços urbanos, uma vez que, à primeira metade do século XIX, a consolidação de um novo perfil na economia e as amarras estruturais a um efetivo desenvolvimento manufatureiro/industrial vão legar à conta do rural os números do crescimento populacional ou das venturas da economia. O especial interesse em São João deve-se mesmo ao fato de ter postergado por algum tempo a perda desse am- 
biente urbano setecentista, exatamente por conta do impulso de seu desenvolvimento comercial, deixando que se ensaiassem assim transições da sociabilidade setecentista para uma animosidade aos ares do século XIX, mormente a partir das influências e ligações com a Corte no Rio de Janeiro. A principal diferença entre São João e Vila Rica está assim no 'ritmo' com que o século XIX lhes chega, ou talvez ainda, no passo em que o século XVIII vai lhes deixando. Exatamente essa síncope, é o lugar de experiências diferenciadas de continuidades e rupturas visíveis no cotidiano das pessoas das duas cidades.

\section{NOTAS}

${ }^{1}$ O presente artigo baseia-se em parte de um capítulo da dissertação Vila Rica - São João del Rey: as voltas da cultura e os caminhos do urbano entre o século XVIII e o XIX, defendida junto ao PPGH da UFF em 2002. Uma versão anterior foi também publicada em: CUNHA, Alexandre M. Paisagem e População: algumas vistas de dinâmicas espaciais e movimentos da população nas Minas do começo do Dezenove. In: ENCONTRO NACIONAL DE ESTUDOS POPULACIONAIS, XIII. Anais... Ouro Preto: Abep, 2002.

${ }^{2}$ A discussão metodológica e conceitual acerca do trabalho com regionalizações históricas, assim como o mapa apresentado pode ser encontrado em: CUNHA, Alexandre M.; SIMÕES, Rodrigo F.; PAULA, João A. de. "História Econômica e Regionalização: contribuição a um desafio teórico-metodológico". ENCONTRO NACIONAL DE ECONOMIA DA ANPEC, XXXIII. Anais... Natal, 2005.

${ }^{3}$ FONSECA, Cláudia D. Agentes e contextos das intervenções urbanísticas nas Minas Gerais do século XVIII. Revista Oceanos, Lisboa, Comissão Nacional para as Comemorações dos Descobrimentos Portugueses, n.41 ("A Construção do Brasil Urbano"), jan.-mar., 2000, p.88.

${ }^{4}$ SAINT-HILAIRE, Auguste de. Viagem às nascentes do Rio São Francisco. Belo Horizonte: Itatiaia; São Paulo: Edusp, 1974. p.130.

${ }^{5}$ POHL, Johann E. Viagem no interior do Brasil. (Trad. Milton e Eugênio Amado). Belo Horizonte: Itatiaia; São Paulo: Edusp, 1976. p.86-7.

${ }^{6}$ SPIX, Johann B. von; MARTIUS, Carl Friedrich Ph. von. Viagem pelo Brasil (1817-1820). (Trad. Lucia Furquim Lahmeyer). Belo Horizonte: Itatiaia; São Paulo: Edusp, 1981. v.1, p.194.

${ }^{7}$ LUCCOCK, John. Notas sobre o Rio de Janeiro e partes meridionais do Brasil. Belo Horizonte: Itatiaia; São Paulo: Edusp, 1975. p.301.

${ }^{8}$ RUGENDAS, João M. Viagem pitoresca através do Brasil. Belo Horizonte: Itatiaia; São Paulo: Edusp, 1979. p.66.

${ }^{9}$ BUNBURY, Charles J. F. Viagem de um naturalista inglês ao Rio de Janeiro e Minas Gerais (1833-1835). (Trad. Helena Garcia de Sousa). Belo Horizonte: Itatiaia; São Paulo: Edusp, 1981. p.96.

10 “.... é atualmente munida de uma só torre, que se acha destacada dela; acham-se porém em curso, projetos de reconstrução da fachada, com dois campanários que, de acordo com o desenho apresentado, serão altos e bem proporcionados." LUCCOCK, John. Notas..., p.303. 
${ }^{11}$ MATOS, Raimundo J. da C. Corografia Histórica da Província de Minas Gerais (1837). Belo Horizonte: Itatiaia; São Paulo: Edusp, 1981. v.1, p.115.

${ }^{12}$ WALSH, Robert. Notícias..., v.2, p.74.

${ }^{13}$ POHL, Johann E. Viagem..., p.87.

${ }^{14}$ SPIX \& MARTIUS. Viagem..., v.1, p.194.

${ }^{15}$ MAWE, John, Viagens..., p.123.

${ }^{16}$ SAINT-HILAIRE, Auguste de. Viagem pela Província do Rio de Janeiro e Minas Gerais. Belo Horizonte: Itatiaia; São Paulo: Edusp, 1975. p.70.

${ }^{17}$ SAINT-HILAIRE, Auguste de. Viagem pela Província do Rio de Janeiro e Minas Gerais, p.70-1. ${ }^{18}$ POHL, Johann E. Viagem..., p.397.

${ }^{19}$ Arnaud Julien Pallière chega ao Brasil juntamente com Thomas Ender, na comitiva da imperatriz Leopoldina, em 1817. Suas vistas de Vila Rica fazem parte de uma tarefa a ele encomendada por D. Pedro I, e que consistia na realização de uma série de telas retratando as principais cidades do Império ao redor do Rio de Janeiro. Cf. AGUILAR, Nelson (curador geral). O olhar distante / The distant view. Catálogo da Mostra do Redescobrimento — 2000 (Parque Ibirapuera, SP). São Paulo: Associação Brasil 500 Anos/Artes Visuais, 2000. p.146.

${ }^{20}$ VASCONCELLOS, Sylvio de. Vistas de Ouro Preto. In: Arquitetura no Brasil: pintura e outros temas. Belo Horizonte: Escola de Arquitetura da UFMG, 1959. p.51. Ver também: WAGNER, Robert; BANDEIRA, Júlio. Viagem ao Brasil nas aquarelas de Thomas Ender, 1817-1818. Petrópolis: Kapa, 2000. Tomo 3.

${ }^{21}$ Ibidem, p.50.

${ }^{22}$ POHL, Johann E. Viagem..., p.396. (Grifo nosso).

${ }^{23}$ WALSH, Robert. Notícias..., v.2, p.101.

${ }^{24}$ SAINT-HILAIRE, Auguste de. Viagem pela Província do Rio de Janeiro e Minas Gerais..., p.63.

${ }^{25}$ VASCONCELLOS, Sylvio de. "Vistas...”, p.55.

${ }^{26}$ Sobre essa leitura da especificidade do espaço da mineração em Minas no século XVIII a partir de uma matriz de produção que determina desde o primeiro momento sua condição urbana, os seguintes textos podem ser consultados: MONTE-MÓR, Roberto L. de M. Gênese e estrutura da cidade mineradora. Belo Horizonte: Cedeplar/FaCE/UFMG, 2001 (Texto para Discussão, n.164); CUNHA, Alexandre M.; MONTE-MÓR, Roberto L. de M. A Tríade Urbana: construção coletiva do espaço, cultura e economia na passagem do século XVIII para o XIX em Minas Gerais. In: SEMINÁRIO SOBRE A ECONOMIA MINEIRA, IX. Anais... Belo Horizonte: Cedeplar/FaCE/UFMG, 2000; CUNHA, Alexandre M. Vila Rica - São João del Rey: as voltas da cultura e os caminhos do urbano entre o século XVIII e o XIX. Dissertação (Mestrado em História) — ICHF, UFF, Niterói, 2002.

${ }^{27}$ SPIX \& MARTIUS, Viagem..., v.1, p.207.

${ }^{28}$ A respeito do tema da centralidade de Vila Rica, e do antigo núcleo minerador, na estrutura urbana de Minas no século XIX, referência central é o competente trabalho de Mário Marcos RODARTE. O caso das Minas que não se esgotaram: a pertinácia do antigo núcleo 
central minerador na expansão da malha urbana da Minas Gerais Oitocentista. Dissertação (Mestrado em Economia) — Cedeplar, UFMG, Belo Horizonte, 1999.

${ }^{29}$ RUGENDAS, João M. Viagem pitoresca..., 1979, p.72.

${ }^{30}$ As perdas populacionais ao longo dos últimos anos do século XVIII provavelmente fizeram aumentar ainda mais a concentração relativa das atividades estritamente urbanas na cidade. O número de oficiais mecânicos e envolvidos no comércio é assim especialmente flagrante no começo do século XIX. Para análises sobre a estrutura ocupacional de Vila Rica no período a referência principal é: COSTA, Iraci del Nero da. Vila Rica: população (1719-1826). São Paulo: IPE/USP, 1979.

${ }^{31}$ SPIX \& MARTIUS. Viagem..., v.1, p.205.

${ }^{32}$ Cf. SLENES, Robert W. Os múltiplos de porcos e diamantes: a economia escrava de Minas Gerais no século XIX. Estudos Econômicos, São Paulo, v.18, n.3, p.449-95, 1988.

${ }^{33}$ Laird W. Bergad, partindo da constatação de que o sumário populacional de 1776 não incluía a região de Minas Novas [informação creditada às "Memórias Históricas da Província de Minas Geraes”, RAPM, Belo Horizonte, v.XII, 1908, p.523-639], por conta das antigas contendas entre Minas e Bahia pela posse desses territórios, procede a uma estimativa para a população de Minas Novas em 1776, a partir dos dados desagregados de 1808, e inclui o total na comarca do Serro Frio. Esses resultados foram originalmente apresentados em BERGAD, Laird W. Demographic Change in a Post-Export Society: The Population of Minas Gerais, Brazil, 1776-1821. Journal of Social History, v.29, n.4, 1996, p.895-932. Ver também: BERGAD, Laird W. Slavery and the Demographic and Economic History of Minas Gerais, Brazil, 17201888. Cambridge: Cambridge University Press, 1999. p.82-92.

${ }^{34}$ Preferiu-se o uso dos dados coligidos por Raimundo de Cunha Matos em sua Corografia histórica, em vez das estatísticas para o ano de 1821, apresentadas pelo Barão de Eschwege, mais freqüentemente utilizadas pela historiografia mineira, pela possibilidade de se identificar com precisão os distritos pertencentes a cada uma das comarcas e, a partir daí, ajustar melhor as correspondências com os dados de 1835 e também 1776. A relativa imprecisão na data a que se referem os dados deve-se ao fato de ter Cunha Matos coligido documentos de natureza diversa, tanto civil como eclesiástica, produzidos em épocas variadas; não obstante, a utilização de 1820 representa uma aproximação consistente da tendência que parece predominar no conjunto, também no confronto com a notícia estatística de Eschwege.

${ }^{35}$ Os dados de crescimento anual se referem à coluna imediatamente anterior, à exceção obviamente das duas estimativas para 1776, em que ambas focalizam o ano de 1721, e dos dados para o ano de 1786, em que o cálculo da taxa de crescimento anual refere-se à estimativa original de 1776, uma vez que as críticas feitas por Bergad às impropriedades no conjunto da população para 1776 , provavelmente seriam válidas também para 1786 , favorecendo assim uma comparação mais acurada do ritmo efetivo do crescimento populacional.

${ }^{36}$ A comarca de Paracatu é criada, em um desdobramento da comarca de Sabará, por um alvará de 17 de maio de 1815, ficando-lhe a partir daí pertencentes os julgados que já existiam a oeste do rio São Francisco. Logo no ano lhe são anexados os julgados de Araxá e Desemboque, pertencentes a Goiás até então. A participação relativa da comarca de Paracatu no conjunto da população atribuída aqui a Sabará pode ser vista desagregando os dados. Sendo assim, em 1820 a comarca de Sabará sozinha tinha 119.620 habitantes $(21,7 \%$ da população total), enquanto a de Paracatu tinha 23.220 (4,21\%). Em 1835 a comarca de 
Sabará passa a ter 146.595 habitantes $(21,1 \%)$ enquanto Paracatu passa para 43.190 (6,22\%). As taxas de crescimento médio para Sabará entre 1820 e 1835 ficam assim em 1,36 por cento ao ano, enquanto para Paracatu no mesmo período alcançam 4,14 por cento.

${ }^{37}$ Além da contribuição fundamental dos trabalhos de Roberto Martins para a discussão da entrada de escravos africanos nas Minas do século XIX, uma referência importante são os escritos de Manolo Florentino, que sobre a comarca do Rio das Mortes comenta: "a população das Gerais cresceu 61\%, enquanto naquela comarca [Rio das Mortes] tal índice alcançou $158 \%$, dados que indicam tanto o deslocamento demográfico das antigas áreas de mineração para o Sul como também o incremento das importações de escravos. Por isso, o número de negros e mulatos em Rio das Mortes passou de um quinto para mais de um terço de sua população total entre 1776 e 1821, ano em que concentrava quase metade (84.995 cativos) de todos os escravos das Gerais". FLORENTINO, Manolo. Em costas negras, uma história do tráfico de escravos entre a África e o Rio de Janeiro (séculos XVIII e XIX). São Paulo: Companhia das Letras, 1997. p.39.

${ }^{38}$ Cf. PEIXOTO, Léa Q. R. Principais antigos caminhos fluminenses para as Minas Gerais. Rio de Janeiro: Imprensa Estadual, 1951. p.85.

${ }^{39} \mathrm{Um}$ ponto importante a ser destacado, e que se relaciona às opções para a correspondência entre os conjuntos de dados disponíveis, é a inclusão do termo de Queluz na comarca do Rio das Mortes ao longo das datas analisadas. As áreas correspondentes ao que seria o termo de Queluz pertencem, em quase sua totalidade, à comarca do Rio das Mortes, como bem se vê no auto de criação da vila em 1790. Cf. RAPM, ano II, 1897, p.105-7. Somente em 1829 o termo da vila passaria à comarca de Ouro Preto. Não obstante os dados de Cunha Matos se referirem a um período anterior à conclusão de sua corografia (1837), ele já agrega o termo à comarca de Ouro Preto na apresentação de seus dados. O mesmo corte é dado também aos mapas populacionais de 1833-1835. O objetivo de apresentar aqui o termo na comarca do Rio das Mortes é, portanto, estabelecer a correspondência dos valores totais para a comarca com os dados de 1776.

${ }^{40}$ MATOS, Raimundo J. da C. Corografia..., v.1, p.124.

${ }^{41}$ WACHTER, Kenneth W.; HAMMEL, Eugene A.; LASLETT, Peter. Statistical studies of historical social structure, New York: Academic Press, 1978. cap.11, "Age Pyramid Variances", p.189-93.

${ }^{42}$ Uma vez que o foco da análise são os processos de migração espontâneos lidos nessa mobilidade acentuada da população por conta do arrefecimento econômico de certas áreas do território mineiro e do desenvolvimento de outras, dar-se-á enfoque somente à população livre ou liberta, mesmo reconhecendo-se a centralidade da leitura dos fluxos de migração forçada, na importação de escravos, para a leitura acurada do desenvolvimento de certas regiões.

${ }^{433}$ COSTA, Iraci. Vila Rica..., p.140-4.

${ }^{44}$ COSTA, Iraci. Minas Gerais: estruturas populacionais típicas. São Paulo: Edec, 1982. p.53.

${ }^{45}$ COSTA, Iraci. Minas Gerais..., p.56.

${ }^{46}$ COSTA, Iraci. Minas Gerais..., p.71. 